\title{
Agriculture and forestry impact assessment for tephra fall hazard: fragility function development and New Zealand scenario application
}

\author{
Heather M. Craig ${ }^{\star \alpha}, \beta$, Thomas M. Wilson ${ }^{\alpha}$, Christina Magill $\gamma$, Carol Stewart ${ }^{\delta}$, Alec J. Wild $^{\epsilon}$ \\ ${ }^{\alpha}$ School of Earth and Environment, University of Canterbury, Private Bag 4800, Christchurch 8140, New Zealand.

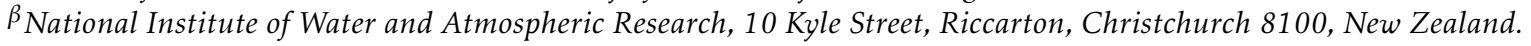

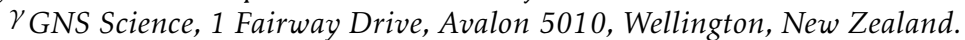 \\ ${ }^{\delta}$ School of Health Sciences, College of Health, Massey University, PO Box 756, Wellington 6140, New Zealand. \\ ${ }^{\epsilon}$ National Institute of Water and Atmospheric Research, 41 Market Place, Auckland 1010, New Zealand.
}

\begin{abstract}
Developing approaches to assess the impact of tephra fall on agricultural and forestry systems is essential for informing effective disaster risk management strategies. Fragility functions are commonly used as the vulnerability model within a loss assessment framework and represent the relationship between a given hazard intensity measure (HIM; e.g. tephra thickness) and the probability of impacts occurring. Impacts are represented using an impact state (IS), which categorises qualitative and quantitative statements into a numeric scale. This study presents IS schemes for pastoral, horticultural, and forestry systems, and a suite of fragility functions estimating the probability of each IS occurring for 13 sub-sectors. Temporal vulnerability is accounted for by a 'temporality/seasonality coefficient,' and a 'fluoride toxicity coefficient' is included to incorporate the increased vulnerability of pastoral farms when tephra is high in leachable fluoride. The fragility functions are then used to demonstrate a deterministic impact assessment with current New Zealand exposure.
\end{abstract}

Keywords: Tephra; Volcanic ashfall; Agriculture; Impact assessment; Vulnerability; Fragility functions; RiskScape

\section{INTRODUCTION}

Assessing the extent and severity of agricultural and forestry impacts from tephra fall hazards and their causal mechanisms is essential when developing disaster risk management strategies. It is well documented that tephra can directly and indirectly impact a range of agricultural and forestry systems and cause both physical and chemical damage [Cook et al. 1981; Cronin et al. 1998; Neild et al. 1998; Zuccaro et al. 2008; Wilson et al. 2011a; Craig et al. 2016b]. Yet there have been limited attempts to quantify potential agricultural impacts within natural hazard impact/risk assessment frameworks [MIAVITA 2012; Jenkins et al. 2014b].

Natural hazard risk assessments for agricultural and forestry systems use hazard and vulnerability information to quantify the probability of different production changes and/or damage to an exposed region. In order to accurately undertake risk assessments, a quantified understanding of the following is required: 1) hazard intensity metrics (HIMs) and spatial constraints (i.e. the area affected by tephra fall with respect to deposit thickness); 2) identification of exposed elements (i.e. the type and location of farms affected); and 3) the vulnerability of exposed elements to the hazard (i.e. the susceptibility of elements to impact from the hazards)

${ }^{*}$ Corresponding author: heather.craig@niwa.co.nz
[Wilson et al. 2014a]. Previous studies have identified that tephra fall impacts on agriculture and forestry will be determined by the exposed farm characteristics, climate, time of year, vegetation/crop type and morphology, existing risk management and the wider ecological system properties and health, in addition to the type, volume and duration of tephra fall [Cook et al. 1981; Cronin et al. 1998; Wilson and Kaye 2007; Wilson et al. 2011a]. Currently this complexity in vulnerability is not well considered in available volcanic impact and risk assessment tools. There have been limited attempts to undertake agricultural and forestry risk assessments for tephra fall with previous studies focused on creating generalised models covering a broad range of agricultural and forestry systems, where impacts typically increase as tephra thicknesses or loading reach a hazard intensity threshold [Jenkins et al. 2014a; Jenkins et al. 2014b], or fragility functions were proposed from relatively limited datasets and expert judgement [Wilson and Kaye 2007].

This study aims to advance work in this area by incorporating impact data from previous impact assessments with new studies and expert adjustment of data to provide a suite of fragility functions for a range of agricultural types, including forestry. These can be applied in a range of international settings but will be most accurate in temperate environments due to most 
of the data points used to create the functions being taken from these climates. The focus of this study is assessing direct impacts due to tephra on agricultural products (i.e. on the crops/pasture/livestock), and does not take into account losses across the wider agricultural enterprise or secondary effects such as loss of employment or impacts on dependent services, which would affect the wider agroeconomy.

Functions presented here incorporate a range of vulnerability information by considering farm type, farm size (larger farms may have better access to machinery, irrigation and other assets), farming intensity (used as a proxy for the climatic zone the farm is in), the farming activities at the time the tephra fall occurred, and the leachable fluoride chemistry of the deposit (fluoride is the only leachable element considered here due to the absence of impact information linked to other elements) [Cronin et al. 2003; Flueck 2016; Stewart et al. 2016]. Finally, this study applies the new suite of fragility functions as the vulnerability input within a deterministic impact assessment for agriculture and forestry in New Zealand using the mapped tephra fall deposit isopachs from the 1314 CE Kaharoa, and 1995 and 1996 Ruapehu eruptions.

\section{VULNERABILITY ASSESSMENTS}

Vulnerability is an essential input into robust volcanic risk and impact assessments [Wilson et al. 2012; Blake et al. 2015]. Vulnerability can be represented using a variety of methods, from simplistic qualitative descriptions to fully quantitative fragility functions (Supplementary Material 1). The most robust tools to represent vulnerability are generally considered to be damage and fragility functions, as they both show a continuous relationship between hazard and impact, rather than discrete thresholds associated with damage/impact states. However, the development of these functions requires a quantitative understanding of the impacts that will occur when a given asset is exposed to a particular HIM, which may be difficult to build if there are insufficient data [Reese and Ramsay 2010].

Agricultural and forestry damage functions measure loss of production, or a damage ratio for a particular hazard intensity; whereas fragility functions assign a probability of a particular impact level being reached or exceeded [Tarbotton et al. 2015]. Fragility functions that use a probabilistic approach are more suited to the diversity in agricultural systems where it is difficult to predict an absolute impact level across a variety of settings. Damage or impact states represent defined asset impact categories, which each have a qualitative description of impact and often a quantitative measure (such as percentage damage or repair cost). This allows for observational data to be placed on a numeric scale [Blong 2003].

A comprehensive understanding of the different agricultural and forestry characteristics determining vul- nerability is needed to undertake any quantitative vulnerability assessment [Wild et al. 2019]. Agriculture is comprised of a range of diverse sectors (including pastoral and horticulture), which each use unique farming methods. Agricultural and forestry vulnerability assessments are further complicated by environmental considerations, which can influence the size and intensity of farming, and the pre-existing conditions of animals and crops [Craig et al. 2016b]. Additionally, the exposed farms access to assets such as machinery, shelter, and feed stores is important [Wilson et al. 2011a]. Tephra fall also presents challenges, as it can cause impacts due to both its physical and chemical nature, making it difficult in incorporate all causal mechanisms into impact models. The physical properties of a tephra deposit (such as thickness, loading, and grain size [Wilson et al. 2011b]), and the environmentally available chemical concentrations (such as fluoride [Stewart et al. 2016]) ideally both need to be quantified in order to create an accurate vulnerability assessment of the tephra to agricultural systems [Stewart et al. 2020]. Tephra falls with high soluble fluoride contents can lead to livestock developing fluorosis, which leads to dental lesions, lameness, and gastrointestinal distress; and therefore, increased production losses [Araya et al. 1990; Flueck 2013].

There are very few publicly available agricultural or forestry vulnerability models for tephra fall. Widely applicable damage/impact state estimates for agricultural impacts due to tephra fall were developed as part of the Global Assessment Report 2015 (GAR-15) on Disaster Risk Reduction for the United Nations - International Strategy for Disaster Reduction (UN-ISDR) [Jenkins et al. 2014b]. However, these were designed for national level assessments, which do not account for vulnerability characteristics (such as seasonal variations, intensity of farming, specific farm types, etc.) at an individual farm level. The functions contained in Wilson and Kaye [2007] are the most comprehensive set of publicly available functions. These were applied in the Bay of Plenty region, New Zealand, [Thompson et al. 2017] and in agricultural economic loss estimates for a Mt. Baekdu, Korea, eruption scenario [Lee et al. 2013; Yu et al. 2014]. A limitation of these functions is that they were largely developed from expert judgement, albeit guided by the limited available impact data at the time.

\section{Methodology}

Agricultural and forestry tephra fragility functions were created by assessing the probability of a farm exceeding an impact state (IS) at a given HIM. Accurate and consistent measurement of the HIM associated with each impact measure is needed to form the independent variable of the fragility curve. The most used HIMs when considering tephra fall impacts are tephra thickness or loading [Wilson et al. 2014a]. When se- 
lecting a HIM it must be: 1) directly related to the intensity of impacts; 2) easily measurable and repeatable in future empirical studies; 3 ) previously measured in post-event impact assessments; and 4) preferably able to be simulated by analytical hazard models [Wilson et al. 2017]. This study adopts compacted tephra thickness $(\mathrm{mm})$ as it is easily quantifiable in the field and the HIM most consistently recorded by impact assessment studies. Tephra loading may be converted to thickness if the deposit density is known or can be estimated. It is likely that for some agricultural infrastructure and assets loading would be a more appropriate indicator of impacts; however, loading data are not always collected after an event leading to a poorer understanding of their correlation with impacts.

Impact data were gathered from analytical and empirical sources and guided by expert application of a series of rules, previously applied in Wilson et al. [2017] for the creation of infrastructure impact functions. These three data types are often used in combination to create vulnerability and fragility functions [Rossetto et al. 2014]. The most commonly available empirical source of agricultural and forestry impact from tephra data comes from post-event impact assessment studies [Sword-Daniels et al. 2011; Wilson et al. 2011a; b; Wardman et al. 2012; Lee et al. 2013; Magill et al. 2013; Blake et al. 2015; Craig et al. 2016a; b; Biass et al. 2017; Hayes et al. 2019]. There have been advances in producing impact data in experimental settings; however, these alone are yet to provide sufficient data to adequately inform the development of quantitative vulnerability models [Wardman et al. 2010; Wilson et al. 2014b; Blake et al. 2016; 2017; Sivarajan et al. 2017; Blake et al. 2018].

This study used 207 individual data points to create the suite of fragility functions. These were either from individual farm sites (where detailed impact assessment survey information was available) or from studies that aggregated general trends in agricultural or forestry impacts [Wilson and Kaye 2007; Blong 2012; Jenkins et al. 2014b]. This included observational and measured data from numerous eruptions between 1943 and 2016, including Baekdu (Korea), Calbuco (Chile), Chaitén (Chile), Colima (Mexico), Etna (Italy), Furnas (Azores Islands), Eyjafjallajokull (Iceland), Hekla (Iceland), Hudson (Chile), Kelud (Indonesia), Merapi (Indonesia), Mt. St. Helens (United States), Pacaya (Guatemala), Paracutin (Mexico), Pinatubo (Philippines), Puyehue-Cordón Caulle (Chile), Ruapehu (New Zealand), Sakurajima (Japan), Shinmoedake (Japan), Tarawera (New Zealand), Tungurahua (Ecuador), and Vesuvius (Italy) [Sword-Daniels et al. 2011; Wilson et al. 2011a; b; Wardman et al. 2012; Lee et al. 2013; Magill et al. 2013; Blake et al. 2015; Craig et al. 2016a; b; Biass et al. 2017; Hayes et al. 2019].

Agricultural and forestry fragility functions were developed using these data through the following steps.
Firstly, Impact State (IS, Impact State label used to denote the inclusion of production loss as well as direct damage) schemes were developed for each sector [Craig et al. 2016a; b] (see Section 3.1). Secondly, these ISs were assigned to empirical impact data points from previous vulnerability studies and case studies (see Section 3.2.1). The approach of grouping data into ISs allowed observational points to be aggregated rather than relying on the repeatability of a single event. This better reflects the complexity of agricultural and forestry systems and the impacts of tephra fall. A set of 13 linear fragility functions for tephra fall were created, following the method of Wilson et al. [2017], which has also been previously employed to create seismic and flooding fragility functions [Porter et al. 2007; Reese and Ramsay 2010; Reese et al. 2011; Rossetto et al. 2013; Tarbotton et al. 2015; Wilson et al. 2017; Rossetto and Ioannou 2018]. Finally, an expert adjustment step was undertaken to complete functions where insufficient data existed. This was done using a set of 'rules' that were applied to ensure that the functions showed the relationship between increased tephra thickness and severity of impacts (see Section 3.2.2). An overview of the methodological process is presented in Figure 1.

\subsection{Impact state schemes and function sectors}

IS schemes were developed for pastoral farming (including dairying), horticulture and forestry using previous observational studies and impact assessments to assess key indicators of production loss and damage [Eggler 1963; Georgsson and Petursson 1972; Thorarinsson and Sigvaldason 1972; Rees 1979; Cook et al. 1981; Araya et al. 1990; Inbar et al. 1995; Mercado 1996; Cronin et al. 1997; 1998; Dahlgren et al. 1999; Johnston et al. 2000; Cronin et al. 2003; Wilson and Cole 2007; Wilson et al. 2011a; Craig et al. 2016b; Wantim et al. 2018]. Percentage production losses associated with each IS were determined by groupings of empirical data and the production losses reported, rather than being arbitrarily defined.

\subsection{Fragility functions}

\subsubsection{Data organisation}

Thirteen sub-sectors were identified as being suitable for having unique fragility function sets. Due to differences in plant morphology and physiology, fragility functions were developed for the following groups of horticulture (classified according to the edible portion of the plant; Arteca [2015]: root vegetables (e.g. carrots, potatoes, onions, etc.); leafy vegetables (e.g. lettuce, spinach, cabbage, etc.); non-tree fruiting vegetables (e.g. strawberries, peas, etc.); tree crops (e.g. apples, citrus, etc.); cereals (e.g. wheat, oat, barley, etc.); 

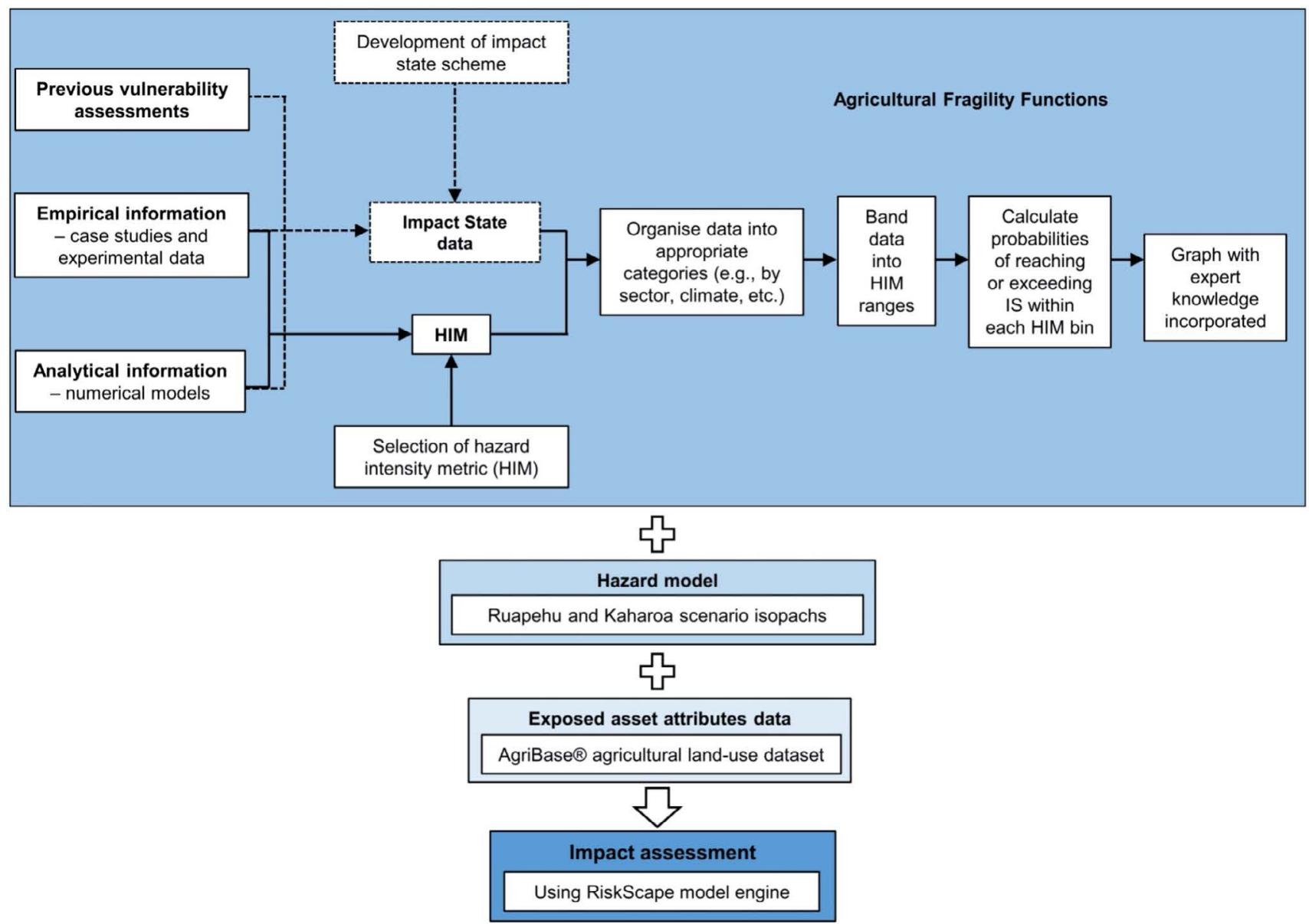

Figure 1: Overview of the process of the creation of fragility functions and the information inputs and components of risk/impact assessments, with the white boxes showing the data and methods applied in this study.

viticulture (grape growing); and paddy farming. We are unable to consider further differences in vegetation morphology (e.g. hairy versus glaborous fruit types) due to the small sample size. These differ slightly from schemes that have previously been applied, notably by the MIAVITA (Mitigate and Assess risk from Volcanic Impact on Terrain and human Activities) project, as they focus primarily on the portion of the plant that is commercially valuable or a food source [MIAVITA 2012].

To account for vulnerability differences within pastoral farming, farms were separated into small and large. The size threshold was chosen based on field observations comparing farms of a similar intensity, where those greater than 500 hectares were commonly observed to have greater access to machinery and supplementary feed increasing their resilience. This may not be applicable for all countries; however, it was found to be useful in the case studies used here (Table 1). Farms were then further divided into high and low intensity using climatic zones as a proxy, where temperate and tropical areas were designated high intensity and semi-arid areas low.

Tephra thickness (the HIM) and IS (impact measure) data were compiled from a range of sources, including case studies, eyewitness reports, and previous vulnerability studies (Table 1), and were divided into the agricultural and forestry sectors shown in Figure 2. To account for temporal/seasonal vulnerability, the impact data were further categorised depending on the farming activity at the time the eruption occurred. Temporal vulnerability levels were assigned based on the farming activities in New Zealand, informed by literature review and field observations [Table 2; Neild et al. 1998; DairyNZ 2018; HorticultureNZ 2019]. Full vulnerability periods are when the farm activities occurring make the farm least resilient to impacts, moderate when there are some activities that deplete resilience but not to its minimum, and low when the farm is most resilient to production losses caused by tephra fall. The same temporality/seasonal coefficients could be applied elsewhere globally with local consideration of farming activities and their impact on vulnerability. Only full vulnerability data points were included in the fragility functions, with data from times of low vulnerability used to inform temporality/seasonal vulnerability coefficients (see Section 3.2.3).

The data points were then arranged by decreasing compacted tephra thickness $(\mathrm{mm})$ and grouped into 
Table 1: Summary of the compacted tephra thickness bands used and the number of observed points within each band. $\mathrm{Te}=$ Temperate, $\mathrm{Tr}=\mathrm{Tropical}, \mathrm{s} \mathrm{Tr}=$ sub-tropical, $\mathrm{sA}=$ semi=arid.

\begin{tabular}{|c|c|c|c|c|c|c|c|c|c|c|}
\hline \multirow{2}{*}{$\begin{array}{c}\text { Sector } \\
\text { Sub-sector }\end{array}$} & \multicolumn{2}{|c|}{ Tephra thickness (mm) } & \multicolumn{6}{|c|}{ No. of observations per IS } & \multirow{2}{*}{$\begin{array}{l}\text { Observation origins } \\
\text { (eruptive vent) }\end{array}$} & \multirow[t]{2}{*}{ Climate } \\
\hline & Intervals & Median & 0 & 1 & 2 & 3 & 4 & Total & & \\
\hline \multicolumn{11}{|c|}{ Small pastoral $(<500 \mathrm{ha})$} \\
\hline \multirow{3}{*}{$\begin{array}{l}\text { Low } \\
\text { intensity }\end{array}$} & $1-5$ & 1 & 2 & 2 & & & & 4 & Hudson, Chile; Chaitén, Chile & $\mathrm{Te}, \mathrm{sA}$ \\
\hline & $6-50$ & 45 & & & 1 & 3 & & 4 & Hudson, Chile; Puyehue-Cordón Caulle, Chile & $\mathrm{Te}, \mathrm{sA}$ \\
\hline & $51-200$ & 100 & & & & 2 & 1 & 3 & Hudson, Chile; Puyehue-Cordón Caulle, Chile & Te, sA \\
\hline \multirow{3}{*}{$\begin{array}{c}\text { High } \\
\text { intensity }\end{array}$} & $1-100$ & 9 & & 3 & & & & 3 & Ruapehu, NZ; Tungurahua, Ecuador & $\mathrm{Te}, \mathrm{Tr}$ \\
\hline & $101-499$ & 200 & & 2 & 4 & 3 & & 9 & $\begin{array}{l}\text { Merapi, Indonesia; Pinatubo, Philippines; Chaitén, } \\
\text { Chile; Hudson, Chile }\end{array}$ & $\mathrm{Te}, \mathrm{sTr}$ \\
\hline & $500-800$ & 550 & & & & 2 & 1 & 3 & Hudson, Chile & Te, sA \\
\hline \multicolumn{11}{|c|}{ Large pastoral $(>500 \mathrm{ha})$} \\
\hline \multirow{3}{*}{$\begin{array}{l}\text { Low } \\
\text { intensity }\end{array}$} & $1-5$ & 1 & 1 & 2 & & & & 3 & Chaitén, Chile & $\mathrm{Te}$ \\
\hline & $6-50$ & 45 & & & 1 & 3 & & 4 & Hudson, Chile; Puyehue-Cordón Caulle, Chile & Te, sA \\
\hline & $51-250$ & 100 & & 2 & & 1 & 1 & 4 & Hudson, Chile; Paricutin, Mexico & $\mathrm{Te}$ \\
\hline \multirow{4}{*}{$\begin{array}{l}\text { High } \\
\text { intensity }\end{array}$} & $1-10$ & 5 & 2 & 2 & 1 & & & 5 & Ruapehu, NZ; Tungurahua, Ecuador; Chaitén, Chile & $\mathrm{Te}, \mathrm{Tr}$ \\
\hline & $11-100$ & 100 & & 6 & 5 & 1 & & 12 & $\begin{array}{l}\text { Ruapehu, NZ; Mt. St. Helens, USA; Pacaya, } \\
\text { Guatemala; Hudson, Chile }\end{array}$ & $\mathrm{Te}, \mathrm{sTr}$ \\
\hline & $101-350$ & 350 & & & 2 & 3 & 1 & 6 & Chaitén, Chile; Paricutin, Mexico & $\mathrm{Te}, \mathrm{sA}$ \\
\hline & $351-800$ & 360 & & & 1 & 1 & 2 & 4 & $\begin{array}{l}\text { Paricutin, Mexico; Puyehue-Cordón Caulle, Chile; } \\
\text { Hudson, Chile }\end{array}$ & \\
\hline \multirow[t]{3}{*}{ Dairying } & $1-10$ & 3 & 2 & 2 & 1 & & & 5 & $\begin{array}{l}\text { Mt. St. Helens, USA; Ruapehu, NZ; } \\
\text { Puyehue-Cordón Caulle, Chile }\end{array}$ & $\mathrm{Te}, \mathrm{sA}$ \\
\hline & $11-100$ & 100 & & 6 & 5 & 1 & & 12 & Ruapehu, NZ; Lonquimay, Chile & $\mathrm{Te}$ \\
\hline & $101-300$ & 300 & & & 2 & 3 & 1 & 6 & Lonquimay, Chile; Hudson, Chile & $\mathrm{Te}, \mathrm{sA}$ \\
\hline \multicolumn{11}{|l|}{ Horticulture } \\
\hline \multirow{3}{*}{$\begin{array}{l}\text { Non-tree } \\
\text { fruit }\end{array}$} & $1-10$ & 3 & 2 & 3 & & & & 5 & Mt. St. Helens, USA; Merapi, Indonesia & $\mathrm{Te}$ \\
\hline & $11-100$ & 20 & & 1 & 1 & 3 & & 5 & Mt. St. Helens, USA; Merapi, Indonesia & $\mathrm{Te}$ \\
\hline & $101-300$ & 200 & & & & 1 & 3 & 4 & $\begin{array}{l}\text { Mt. St. Helens, USA; Merapi, Indonesia; } \\
\text { Shinmoedake, Japan }\end{array}$ & $\mathrm{Te}$ \\
\hline \multirow[t]{3}{*}{ Tree fruit } & $1-20$ & 13 & 3 & 1 & & 1 & & 5 & Tungurahua, Ecuador; Merapi, Indonesia & $\mathrm{Te}$ \\
\hline & $21-99$ & 50 & & 1 & 2 & 3 & & 6 & Merapi, Indonesia & $\mathrm{Te}$ \\
\hline & $100-500$ & 350 & & & 1 & 3 & 2 & 6 & Mt. St. Helens, USA; Merapi, Indonesia & $\mathrm{Te}$ \\
\hline \multirow{3}{*}{$\begin{array}{c}\text { Leafy } \\
\text { vegetables }\end{array}$} & $1-20$ & 5 & 2 & 1 & 3 & 1 & & 7 & Merapi, Indonesia & $\mathrm{Te}$ \\
\hline & $21-99$ & 22 & & & & 4 & 3 & 7 & Merapi, Indonesia; Shinmoedake, Japan & $\mathrm{Te}$ \\
\hline & $100-500$ & 450 & & & & 3 & 3 & 6 & Merapi, Indonesia; Shinmoedake, Japan & $\mathrm{Te}$ \\
\hline \multirow[t]{3}{*}{ Cereals } & $1-19$ & 6 & 3 & 2 & & & & 5 & $\begin{array}{l}\text { Kelud, Indonesia; Mt. St. Helens, USA; Ruapehu, } \\
\text { NZ }\end{array}$ & $\mathrm{Te}$ \\
\hline & $20-100$ & 27 & & 5 & 3 & 1 & & 9 & $\begin{array}{l}\text { Mt. St. Helens, USA; Merapi, Indonesia; Hudson, } \\
\text { Chile; Chaitén, Chile }\end{array}$ & $\mathrm{Te}$ \\
\hline & $101-500$ & 450 & & 3 & 1 & 1 & 2 & 7 & Chaitén, Chile; Tungurahua, Ecuador & $\mathrm{Te}, \mathrm{Tr}$ \\
\hline \multirow{3}{*}{$\begin{array}{c}\text { Root } \\
\text { vegetables }\end{array}$} & $1-20$ & 5 & 2 & 2 & & & & 4 & Ruapehu, NZ; Mt. St. Helens, USA; Chaitén, Chile & Te, sA \\
\hline & $21-99$ & 50 & & 1 & 3 & & & 4 & $\begin{array}{l}\text { Merapi, Indonesia; Ruapehu, NZ; Shinmoedake, } \\
\text { Japan }\end{array}$ & $\mathrm{Te}$ \\
\hline & $100-500$ & 225 & & & 1 & 2 & 1 & 5 & Merapi, Indonesia; Hudson, Chile & Te, sA \\
\hline \multirow[t]{4}{*}{ Viticulture } & $1-10$ & 2 & 1 & 1 & 1 & & & 3 & Etna, Italy; Ruapehu, NZ & $\mathrm{Te}$ \\
\hline & $11-100$ & 50 & & & 2 & 1 & 1 & 4 & Etna, Italy & $\mathrm{Te}$ \\
\hline & $101-500$ & 200 & & & & 1 & 3 & 4 & Etna, Italy & $\mathrm{Te}$ \\
\hline & $1-19$ & 13 & 2 & 4 & 1 & 2 & & 9 & Merapi, Indonesia; Shinmoedake, Japan & $\mathrm{Te}$ \\
\hline \multirow[t]{2}{*}{ Paddy } & $20-100$ & 20 & 1 & 2 & 1 & 3 & 1 & 8 & $\begin{array}{l}\text { Merapi, Indonesia; Shinmoedake, Japan; Kelud, } \\
\text { Indonesia }\end{array}$ & $\mathrm{Te}$ \\
\hline & $101-1000$ & 500 & & & 1 & 3 & 4 & 8 & Kelud, Indonesia & $\mathrm{Te}$ \\
\hline \multicolumn{11}{|l|}{ Forestry } \\
\hline & $1-100$ & 10 & 4 & 1 & & & & 5 & Tongariro, NZ; Ruapehu, NZ & $\mathrm{Te}$ \\
\hline & $101-1000$ & 325 & 3 & 3 & 2 & & & 8 & $\begin{array}{l}\text { Hudson, Chile; Puyehue-Cordón Caulle, Chile; } \\
\text { Chaitén, Chile; Mt. St. Helens, USA }\end{array}$ & $\mathrm{Te}$ \\
\hline & $1001-1600$ & 1350 & & & 2 & 2 & 2 & 6 & Mt. St. Helens, USA & $\mathrm{Te}$ \\
\hline
\end{tabular}




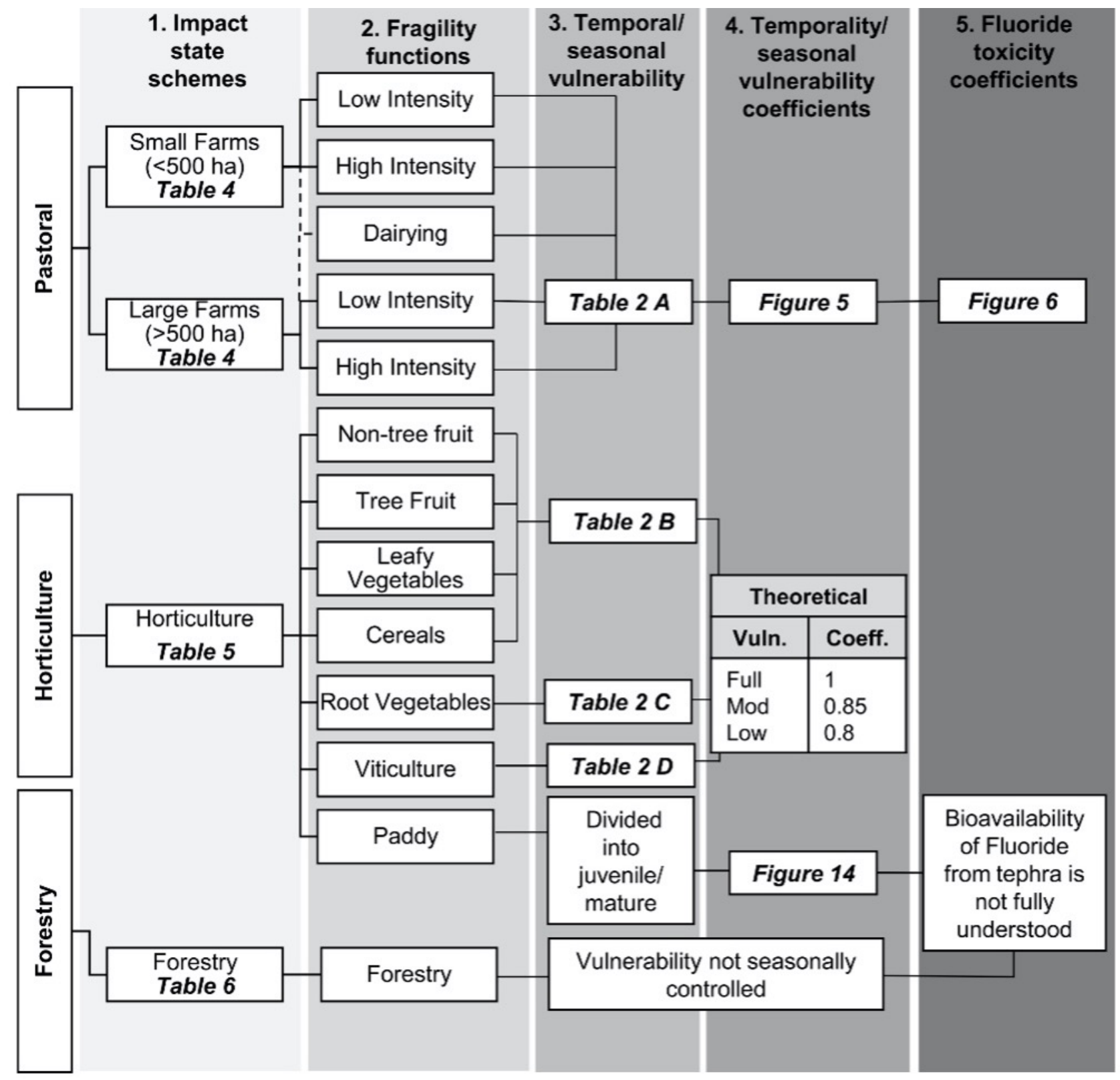

Figure 2: Chart showing the separation of agricultural sectors for damage/production state schemes and fragility functions. Also showing which seasonality and leachable fluoride coefficients will be used for each. Diagram of the datasets created for each agricultural sector for 1) Impact State (IS) schemes (4 sets); 2) Fragility functions (13 functions); 3) Temporality/seasonal vulnerability divisions; 4) Calculated and theoretical temporality/seasonality coefficients; and 5) Fluoride toxicity coefficient for pastoral farming.

'bands' that each had approximately the same number of points (Figure 1). Then for each band, the proportion of data points that reached or exceeded each IS was calculated (y-axis). A corresponding HIM value ( $\mathrm{x}$-axis) for each band was calculated by calculating the median tephra thickness value. The total number of points varied between the agricultural sectors, with a minimum of three points per band (1-10 $\mathrm{mm}$ tephra, viticulture function) (Table 1).

\subsubsection{Function creation}

The probability of an IS being reached or exceeded was plotted against the median tephra thickness for each band. Previous vulnerability and fragility functions have used continuous cumulative lognormal and logarithmic forms; however, this study used a linear form between each data point. This is because the relatively small datasets do not allow for more complex trends to be identified. This means that for each of the fragility functions, there are 3-4 discrete linear equations for each IS. These form the following expressions: 


$$
\begin{array}{rl}
\mathrm{HIM}=0 & P(\mathrm{IS}=\mathrm{IS} 0)=0 \\
t_{0} \leq \mathrm{HIM}<t_{1} & P(\mathrm{IS}>\mathrm{IS} 0)=m_{1} \mathrm{HIM}+c_{1} \\
t_{1} \leq \mathrm{HIM}<t_{2} & P(\mathrm{IS} \geq \mathrm{IS} 1)=m_{2} \mathrm{HIM}+c_{2} \\
t_{2} \leq \mathrm{HIM}<t_{3} & P(\mathrm{IS} \geq \mathrm{IS} 2)=m_{3} \mathrm{HIM}+c_{3} \\
t_{3} \leq \mathrm{HIM}<t_{4} & P(\mathrm{IS} \geq \mathrm{IS} 3)=m_{4} \mathrm{HIM}+c_{4} \\
t_{4} \leq \mathrm{HIM}<t_{x} & P(\mathrm{IS} \geq \mathrm{IS} 4)=m_{4} \mathrm{HIM}+c_{4}
\end{array}
$$

where $t_{1}, t_{2}, t_{3}, t_{4}$, and $t_{x}$ are the tephra thicknesses defining each of the thickness bands; $m_{1}, m_{2}, m_{3}$, and $m_{4}$ are slope constants; and $c_{1}, c_{2}, c_{3}$, and $c_{4}$ are the intercepts. $\mathrm{P}\left(\mathrm{IS} \geq \mathrm{IS}_{x}\right)$ is the probability of a given damage and productivity state being reached or exceeded.

Due to the small empirical dataset available for each category, a set of rules, supported by some expert judgement undertaken in collaboration by the team of authors, was also used to refine the fragility func-

\begin{tabular}{|c|c|}
\hline Farm activity & Vulnerability \\
\hline $\begin{array}{l}\quad[\mathrm{A}] \text { Pastoral } \\
\text { Silage feed primarily being used } \\
\text { (often during winter) } \\
\text { Calving } \\
\text { Lambing } \\
\text { Spring pasture growth }\end{array}$ & $\begin{array}{c}\text { Low } \\
\text { Moderate } \\
\text { Full } \\
\text { Full }\end{array}$ \\
\hline $\begin{array}{l}\text { [B] Horticulture } \\
\text { Frost protection in place } \\
\text { Bud burst } \\
\text { Harvesting } \\
\text { Pruning } \\
\text { Flowering } \\
\text { Germination }\end{array}$ & $\begin{array}{l}\text { Low } \\
\text { Moderate } \\
\text { Moderate } \\
\text { Full } \\
\text { Full } \\
\text { Full }\end{array}$ \\
\hline $\begin{array}{l}\qquad[\mathrm{C}] \text { Root vegetables } \\
\text { Post-germination and } \\
\text { pre-harvesting } \\
\text { Harvesting } \\
\text { Germination }\end{array}$ & $\begin{array}{c}\text { Low } \\
\text { Moderate } \\
\text { Full }\end{array}$ \\
\hline $\begin{array}{l}\quad[\mathrm{D}] \text { Viticulture } \\
\text { Pruning and maintenance (during } \\
\text { winter) } \\
\text { Harvesting } \\
\text { Insecticide spraying } \\
\text { Trimming, leaf plucking, and } \\
\text { irrigation }\end{array}$ & $\begin{array}{c}\text { Low } \\
\text { Moderate } \\
\text { Full } \\
\text { Full }\end{array}$ \\
\hline
\end{tabular}
tions. This was necessary as incomplete datasets can be misleading, particularly at lower ISs (0 and 1), as

Table 2: Generic vulnerability levels, based on the New Zealand agricultural calendar, for farming types [A] pastoral; $[\mathrm{B}]$ non-tree fruit, tree fruit, leafy vegetables and cereals; [C] root vegetables; and [D] viticulture, with farm activities and growth stages. These activity levels were used to define the vulnerability levels used to create the functions and temporality/seasonal coefficients. there is often a bias towards collecting higher severity impact data [Aspinall 2006; Wilson et al. 2014a]. The following instructions were applied to each of the fragility functions: 1) lines representing the probability of each IS being reached or exceeded cannot bisect each other; 2) where the tephra thickness equals zero, there is no impact, therefore no probability of the IS being reached or exceeded; 3) the probability of each IS being reached or exceeded must increase as tephra thickness increases; and 4) the probability of an IS being reached or exceeded (when tephra thickness greater than zero) cannot be zero or one, as it is not possible to know whether an impact will absolutely occur or not occur.

\subsubsection{Temporality/seasonality, fluoride toxicity and} juvenile paddy crop coefficients

To better account for differences in impacts dependent on farm activities at the time the eruption occurs, and the leachable chemistry of the tephra fall deposit, a series of coefficients were calculated. These can be used during times of moderate or low temporal/seasonal vulnerability or when leachable chemistry is elevated in fluoride, to modify the existing fragility functions.

Prior to fragility functions being created, data points were separated into full, moderate, and low tempo$\mathrm{ral} /$ seasonal vulnerability dependent on the time of year the eruption occurred and the associated farming activities at the time (Table 2). These differ between different climatic zones and crops, and ideally would be used to determine the vulnerability level based on an individual farm activity calendar. Empirical data for events that occurred during times of full vulnerability were used to create the primary fragility functions. For pastoral farming, where there was a larger dataset, additional fragility functions were created for the data points at moderate and low vulnerabilities, and a percentage difference was calculated (Figure 4 and Table 7). The moderate and low vulnerability data points were placed in the same tephra bands as the full vulnerability points to allow for a ratio to be calculated.

The temporality/seasonal coefficients proposed for horticultural fragility functions were not calculated values due to the lack of seasonal variation of the data points used to create the functions (Table 1). Therefore, the proposed coefficients (Figure 2) were decided based on consideration of previously proposed tempo$\mathrm{ral} /$ seasonal vulnerability differences [Wilson and Kaye 2007]. Insufficient data prevented the same methodology from being applied to small and low intensity pastoral farms and dairying. Therefore, the functions for large farms are applied to all pastoral farming as a best estimate.

Whilst the individual soluble chemistry of the deposit and the receiving environment will strongly influence leachable fluoride concentrations, there is a link between thicker tephra deposits and an increased in- 
cidence of fluorosis when considering a singular farm type and event [Cronin et al. 1997; Stewart et al. 2016]. This means that the existing fragility functions (which rely on tephra thickness as the independent variable) can be modified to incorporate the change in vulnerability with increased leachable fluoride concentrations, using the same approach as for the temporality/seasonal coefficient.

In order to create a fluoride toxicity coefficient, points with high fluoride concentrations $(>150 \mathrm{mg} / \mathrm{kg}$ ) were excluded from the creation of fragility functions [Cronin et al. 1997; Armienta et al. 2011; Ayris and Delmelle 2012; Cronin et al. 2014; Cabré et al. 2016; Stewart et al. 2016]. Large, high intensity pastoral fragility points with low fluoride concentrations were then subtracted from high fluoride points for each thickness band to give the coefficient. The threshold of $150 \mathrm{mg} / \mathrm{kg}$ of fluoride per kilogram of tephra was used based on research undertaken after previous eruptions and identifying when leachable fluoride concentrations caused livestock illnesses [Rubin et al. 1994; Cronin et al. 2000; 2003; Flueck 2013; Stewart et al. 2016]. No data points with confirmed high fluoride concentrations are available for thicknesses greater than $350 \mathrm{~mm}$ so no coefficient can be calculated at thicknesses greater than this. As with the temporality/seasonal coefficients, fluoride coefficients were not able to be calculated for small, low intensity pastoral, or dairying.

Paddy farming was further divided into juvenile and mature rice crops as juvenile rice crops contaminated with tephra can often be reflooded to minimise production impacts [Wilson et al. 2007]. However, this solution is not practical once the crops have matured [Reyes and Neue 1991]. The juvenile functions were then subtracted from the mature to give a juvenile paddy crop coefficient (i.e. a ratio of the reduction in vulnerability).

\subsection{Deterministic application of fragility functions}

\subsubsection{Agriculture and forestry exposure inventory}

To perform impact assessments a compatible agriculture and forestry inventory dataset was required. The fragility functions were developed to best capture different agricultural types and their associated vulnerabilities, but also to be applied as a risk assessment tool with two available New Zealand agriculture and forestry inventory databases: the 2013 AgriBase ${ }^{\circledR}$ dataset [AssureQuality 2015] and the Land Information New Zealand (LINZ) Land Cover Database version 5.0 [Manaaki Whenua Landcare Research 2020]. Using both these datasets allowed for the division of spatial data into the categories represented by the proposed fragility functions (Supplementary Material 2).

\subsubsection{Impact assessment}

A scenario-based impact assessment was performed for current productive land using the 1995 and 1996 Ruapehu, and 1314 CE Kaharoa tephra fall isopach maps (Table 3). This allowed tephra thickness for these events to be calculated for the centroid of each affected farm [Cronin et al. 1998; Sahetapy-Engel et al. 2014]. The Ruapehu impacts were determined using the appropriate temporality/seasonal vulnerability coefficient for the farm activities at the time of the eruption (i.e. October 1995 and June 1996) but assuming 2015 exposure. These three events were used as they provided a large-scale event scenario (Kaharoa at full vulnerability) and smaller, more frequently occurring events (Ruapehu). Qualitative descriptions of agricultural impacts are also available for the recent Ruapehu events.

Deterministic impact assessments were undertaken using the RiskScape software engine. This software provides a modular framework for performing risk and impact assessments for various hazard scenarios and probabilistic hazard data [Reese et al. 2007]. The system combines hazard, exposure and vulnerability datasets and is applied here using a pipeline developed specifically for this project. A RiskScape pipeline defines the set of data processing steps, where data are passed between the steps and transformed along the way. The pipeline model was set up to take the agriculture and forestry exposure and tephra fall layers, select the appropriate fragility function and calculate the ISs for each farm for each tephra fall scenario.

The percentage of production loss that would occur in each IS was estimated for each of the sectors (pastoral/dairying, horticulture, and forestry). This allowed for a preliminary economic assessment to be undertaken, using the estimated profit per hectare per year values gathered from various sources [MAF 2011; HorticultureNZ 2019; DairyNZ 2020]. These values were taken from aggregated data and are likely not applicable to all regions or individual crop and livestock types; however, they give an initial indication of the scale of direct economic production losses, were these events to occur today.

\section{Results}

\subsection{Impact State (IS) schemes}

The pastoral farm ISs were calculated using two scales to take into account that production losses needed to cause a higher IS are lower for smaller farms as they are more vulnerable to even small productivity changes [Wilson and Kaye 2007; Wilson et al. 2011b] (Table 4). A single IS scheme was developed for horticultural farming as, whilst this category incorporates a range of different types of plants and products (Figure 2), the use of production losses and vegetation damages as 
Table 3: Deterministic scenarios used to apply agricultural fragility functions [Johnston et al. 2000; Sahetapy-Engel et al. 2014].

\begin{tabular}{lcccc}
\hline \multicolumn{2}{c}{ Eruption characteristics } & \multicolumn{2}{c}{ Model modalities } \\
\hline Volcano & Date & VEI & $\begin{array}{c}\text { Temporal/seasonal } \\
\text { vulnerability applied }\end{array}$ & $\begin{array}{c}\text { Fluoride toxicity } \\
\text { coefficient used }\end{array}$ \\
\hline Ruapehu & 14 October 1995 & $<3$ & Full & Yes \\
Ruapehu & 17 June 1996 & $<3$ & Low & Yes \\
Kaharoa & $\sim 1314$ CE & 5 & Full & No \\
\hline
\end{tabular}

indicators means that the IS scheme can be universally applied (Table 5). Forestry is unique compared to pastoral and horticultural agriculture and has a specific set of vulnerabilities, warranting its own IS scheme and associated production loss percentages (Table 6).

\subsection{Agricultural and forestry tephra fragility func- tions}

This section presents the developed fragility functions using the methodology presented in Section 3.1 and Section 3.2. Modifications were undertaken for all curves to abide by the expert adjustment rules presented in Section 3.2.3 (i.e. a higher IS cannot have a lower exceedance probability than a lower IS).

\subsubsection{Pastoral}

Three sets of pastoral fragility functions are presented for high intensity (Figure 3A), low intensity (Figure 3B) and dairy farms (Figure 3C).

Non-dairy pastoral (sheep, beef cattle and deer) farming. A limitation within the pastoral datasets is that IS4 is likely underrepresented due to farmers commonly abandoning land resulting in $100 \%$ production loss (and therefore not able to be visited or interviewed) or issues with sensitivity when selecting case studies during post-event impact assessment (it can be ethically inappropriate to interview farmers who have suffered the greatest losses). Conversely, it is likely that IS3 is somewhat overrepresented. This could be due to bias towards studying farms with significant impacts in post-event impact assessments. A major issue with the dataset for low intensity farming is that the impacts at greater than $100 \mathrm{~mm}$ tephra thickness are poorly constrained, with only three points from higher tephra thicknesses $(>50 \mathrm{~mm})$, and none from greater than $200 \mathrm{~mm}$ (Table 1).

Temporal/seasonal vulnerability was evaluated through the creation of three sets of fragility functions for high intensity, large pastoral farms (Figure 4). This demonstrated a decrease in vulnerability of between 6 and $17 \%$ from time of full vulnerability to times of moderate vulnerability, and 14 and $24 \%$ from full to low vulnerability levels (Table 7).
Fragility functions created using high fluoride data points for pastoral farms demonstrated a 3 to $24 \%$ increase in the probability of reaching a given IS (Figure 5 and Table 8).

Dairy farming. The resulting fragility function for dairying (Figure 3C) demonstrates its greater vulnerability compared to other types of pastoral farming (Figure $3 \mathrm{~A}$ and $\mathrm{B}$ ). We note the dairy farming impact dataset was limited compared to the other pastoral categories, due to both its smaller size and its greater reliance on previous theoretical vulnerability studies (Table 1).

\subsubsection{Horticultural}

Root vegetables. Root vegetables showed a relatively low probability of reaching IS4 even within the highest thickness band (100-500 mm; Figure 6A), compared to other horticulture; however, this would likely be dependent on the maturity of the affected crop. A limitation of the current data set is that there was little information on the specific cause of elevated IS (such as chemical or physical vegetation damage, issues with soil fertility, dehydration, etc.). There was also only minimal information on exact root vegetable types and farm practices.

Leafy vegetables. A limitation of the leafy vegetable data set is the small number of ISO and IS1 points (Table 1). This is likely due to bias in field studies, which have focused mostly on crops that have sustained impact, as well as the full vulnerability of leafy vegetables, where only thin tephra deposits $(<5 \mathrm{~mm})$ are required to cause IS $>1$. The data points with full temporal/seasonal vulnerability did not include any case studies covering the thickness range between 100 and $400 \mathrm{~mm}$. This gap in the data accounts for the wide spacing between data points (at $22.5 \mathrm{~mm}$ and $450 \mathrm{~mm}$ ), where interpolation was relied upon to provide a function (Figure 6A). The increased edible surface area exposed to tephra fall compared to root vegetables is likely the cause of the higher vulnerability shown in the leafy vegetable function, where the probability of reaching or exceeding IS 4 is over $80 \%$ at $\sim 2 \mathrm{~mm}$ (Figure $6 \mathrm{~A}$ ). 
Table 4: Impact state (IS) scheme for small and large pastoral farms (including dairying) with example photographs from post-event impact assessments. Photographs show farms impacted by previous eruptions that are representative of each IS.

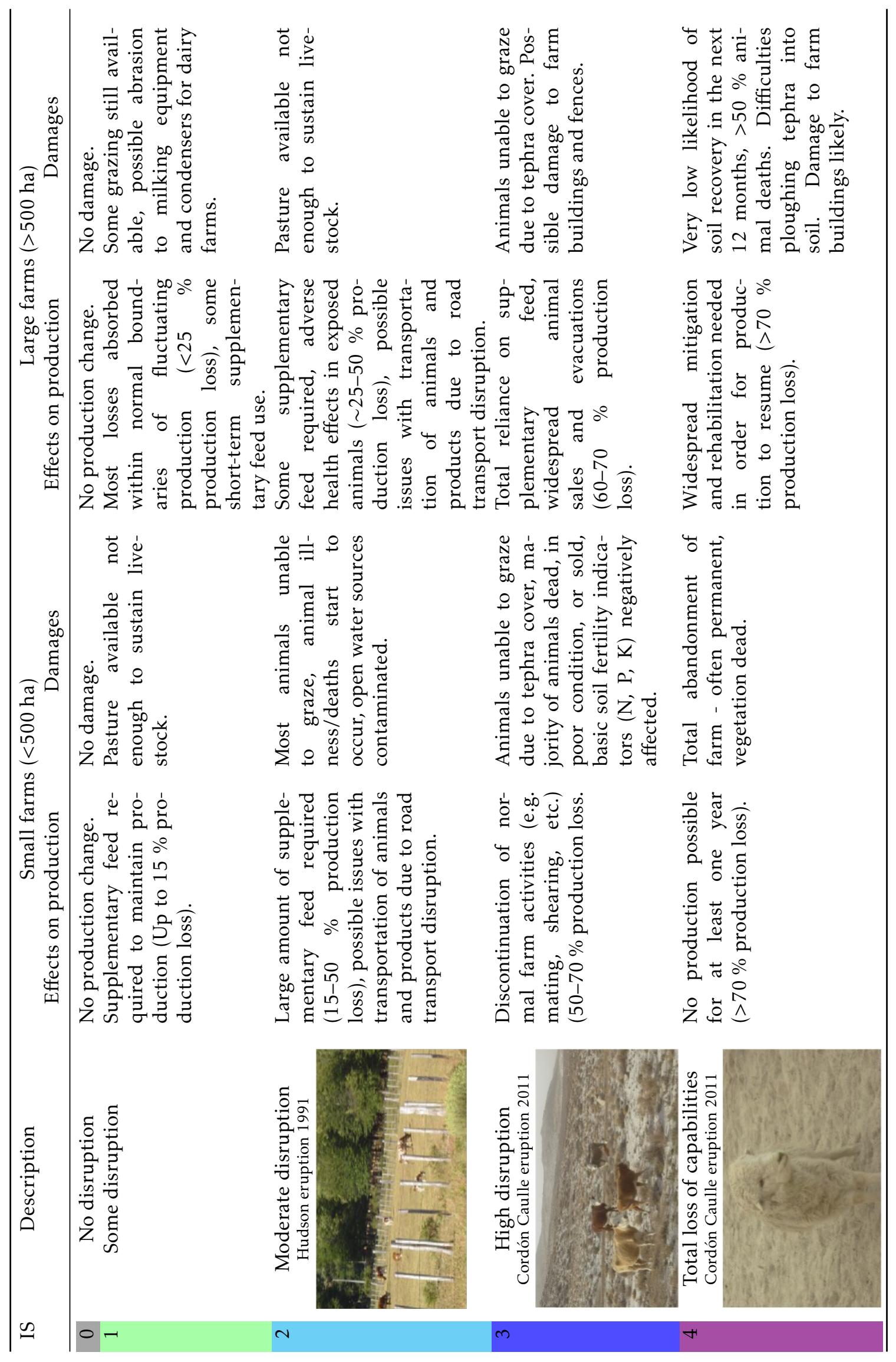


Table 5: Impact state (IS) scheme for horticultural farming with example photographs from post-event impact assessments. Photographs show farms impacted by previous eruptions that are representative of each IS.

\begin{tabular}{|c|c|c|c|}
\hline IS & Description & Effects on production & Damages \\
\hline 0 & No disruption & No production change. & No damage. \\
\hline 1 & Some disruption & $\begin{array}{l}\text { Slightly lower productivity but re- } \\
\text { coverable harvest. }\end{array}$ & $<75 \%$ vegetation covered. \\
\hline \multirow[t]{2}{*}{2} & $\begin{array}{l}\text { Moderate disruption } \\
\text { Kelud eruption } 2014\end{array}$ & Up to $30 \%$ production loss. & $\begin{array}{l}\text { Some plant breakage and damage } \\
\text { to crops within the impacted farm; }\end{array}$ \\
\hline & & & $\begin{array}{l}\text { possible acid burns (due to acidic } \\
\text { leachates coating the tephra and } \\
\text { damaging plant tissue when in con- } \\
\text { tact) and abrasion. }\end{array}$ \\
\hline & $\begin{array}{l}\text { High disruption } \\
\text { Merapi eruption } 2006\end{array}$ & $\begin{array}{l}\text { Rinsing/mitigation needed, } \sim 60 \% \\
\text { production loss. }\end{array}$ & $\begin{array}{l}\text { Most crops within impacted farms } \\
\text { sustain some physical damage (i.e. }\end{array}$ \\
\hline & & & $\begin{array}{l}\text { breakages, vegetation damage, } \\
\text { etc.). }\end{array}$ \\
\hline 4 & $\begin{array}{l}\text { Total loss of capabilitie } \\
\text { Kelud eruption } 2014\end{array}$ & $\begin{array}{l}>90 \% \text { reduction in yield; }>1 \text { season } \\
\text { to recover. }\end{array}$ & $\begin{array}{l}\text { All crops within the impacted farm } \\
\text { damaged in some way. Possible } \\
\text { damage to farm buildings. }\end{array}$ \\
\hline
\end{tabular}

Table 6: Impact state (IS) scheme for forestry plantations. No photographs provided due to reliance on previous studies for forestry data.

\begin{tabular}{|c|c|c|c|}
\hline IS & Description & Effects on production & Damages \\
\hline 0 & No disruption & No production change. & No damage. \\
\hline 1 & Some disruption & $\begin{array}{l}\text { Minor impact to harvesting. Access } \\
\text { roads affected due to poor visibility. }\end{array}$ & No damage to trees. \\
\hline 2 & Moderate disruption & $\begin{array}{l}\text { Moderate impacts to tree harvest- } \\
\text { ing; production losses } \sim 10 \% \text { for } \\
\text { first year. }\end{array}$ & $\begin{array}{l}\text { Some young trees (new plantings) } \\
\text { buried. } 2-10 \text { year old trees suf- } \\
\text { fer branch breakages. Harvestable } \\
\text { trees not damaged. }\end{array}$ \\
\hline 3 & High disruption & $\begin{array}{l}\text { Forestry operations temporarily } \\
\text { cease due to difficult working } \\
\text { environment (i.e. harvesting and } \\
\text { transport machinery can no longer } \\
\text { operate safely). } \sim 50 \% \text { production } \\
\text { loss for first year. }\end{array}$ & $\begin{array}{l}\text { Young plantings often smothered } \\
(>50 \% \text { will not survive). } 2-10 \\
\text { year old trees will suffer breakages. } \\
\text { Harvestable trees will suffer some } \\
\text { breakages. }\end{array}$ \\
\hline 4 & Total loss of capabilities & $\begin{array}{l}\text { Production is halted for many years } \\
\text { due to difficult conditions (machin- } \\
\text { ery cannot operate), over } 80 \% \text { of } \\
\text { trees completely lost. } 100 \% \text { pro- } \\
\text { duction loss for first year. }\end{array}$ & $\begin{array}{l}\text { New plantings all die. } 2-10 \text { year } \\
\text { old trees suffer severe structural } \\
\text { damage. Harvestable trees will sur- } \\
\text { vive (with breakages) but will be } \\
\text { unable to be harvested immediately } \\
\text { due to the very thick deposits. }\end{array}$ \\
\hline
\end{tabular}



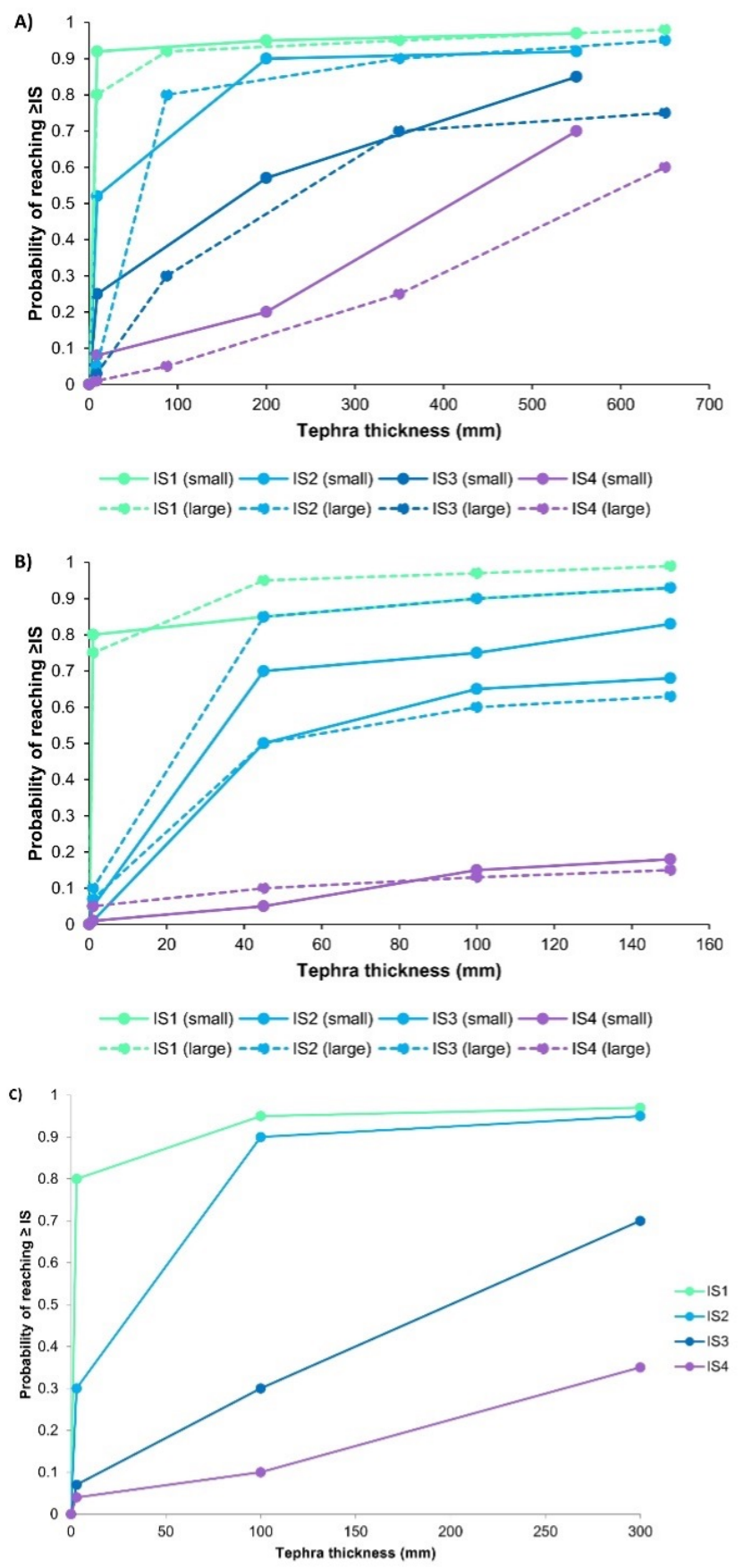

Figure 3: Pastoral fragility function suite for [A] high intensity, non-dairy pastoral farming fragility functions for small and large farms at full vulnerability; $[B]$ low intensity, non-dairy pastoral farming fragility functions for small and large farms at full vulnerability; and [C] dairy farms at full vulnerability.

Non-tree fruiting vegetables. Non-tree fruit crop data gaps include infrequent points between 100- and 300-mm tephra thickness, sparse information about specific differences in impacts between fruit types, and few points at IS2 (Table 1). Non-tree fruit horticulture appears to be less vulnerable to tephra fall impacts than leafy vegetables (Figure $6 \mathrm{~B}$ ), but more vulnerable than root vegetables (Figure 6A).

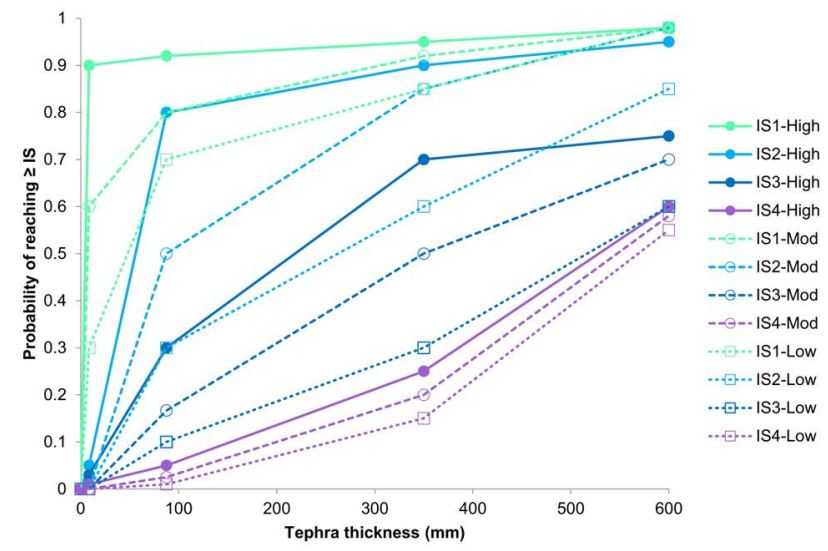

Figure 4: Fragility functions for large, high intensity, nondairy pastoral farms at full temporal/seasonal vulnerability, moderate temporal/seasonal vulnerability, and low temporal/seasonal vulnerability. See Table 7 for calculated values.

Table 7: Calculated temporality/seasonality coefficients values for fragility functions for large, high intensity, non-dairy pastoral farms, created by subtracting line segments shown in Figure 4.

\begin{tabular}{lccc}
\hline Thickness $(\mathrm{mm})$ & Full & Moderate & Low \\
\hline $1-10$ & 1 & 0.94 & 0.86 \\
$11-100$ & 1 & 0.88 & 0.76 \\
$101-300$ & 1 & 0.83 & 0.76 \\
$301-800$ & 1 & 0.91 & 0.84 \\
\hline
\end{tabular}

Tree fruits. Tree fruits were found to be much more resilient to tephra fall compared to other types of horticulture (Figure 6B). This may explain the lack of data at IS4; as the relative resilience means tephra thicknesses need to be extremely high (usually $>300 \mathrm{~mm}$ ) to begin to cause tree fruits to fall into IS4.

Cereals. Impacts to cereal type crops due to tephra fall have been recorded on 19 occasions, including during the 1980 Mt. St. Helens [Cook et al. 1981], 1995 Ruapehu [Cronin et al. 1998], 2006 Merapi [Wilson et al. 2007], 2008 Chaitén (T. M. Wilson, unpub. field notes), 2010 Tungurahua [Sword-Daniels et al. 2011] and 2014 Kelud [Blake et al. 2015] eruptions. However, despite the variety of case studies there are very few IS3 points recorded (Table 1 and Figure 6C).

Viticulture. The creation of viticulture fragility functions relied on previous vulnerability studies [Pevreal 1993; Wilson and Kaye 2007], with only one recorded empirical study after the 2002 Etna eruption [Barnard 2003]. However, despite this limitation fragility functions are proposed using the available points (Figure 6C). 


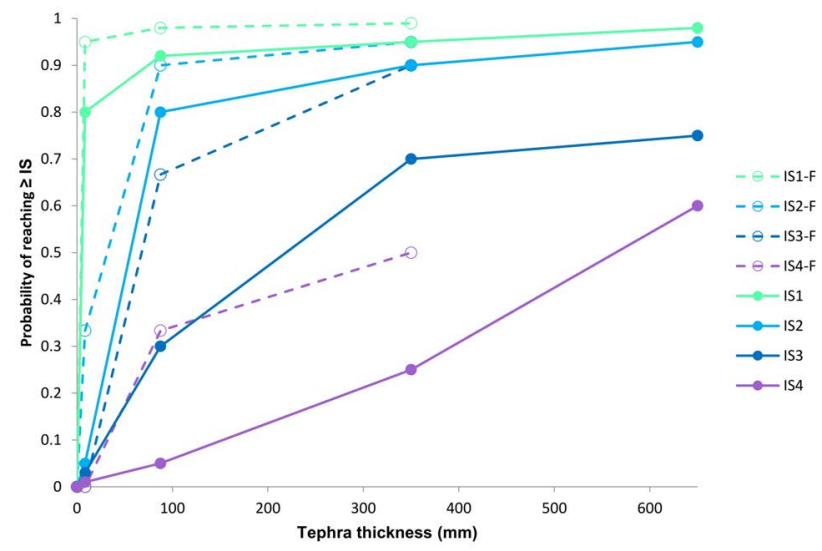

Figure 5: Calculation of a coefficient to account for the higher vulnerability of pastoral farms caused by tephra fall with high leachable fluoride $(>150 \mathrm{mg} / \mathrm{kg})$. Fragility functions for high leachable fluoride events compared to functions for low leachable fluoride events ( $<150 \mathrm{mg} / \mathrm{kg}$ ) for large, high intensity pastoral farming. See Table 8 for calculated values.

Table 8: Calculated fluoride toxicity coefficient values for fragility functions for large, high intensity, non-dairy pastoral farms, created by subtracting line segments shown in Figure 5.

\begin{tabular}{lcc}
\hline Thickness $(\mathrm{mm})$ & $<150 \mathrm{mg} / \mathrm{kg} \mathrm{F}$ & $>150 \mathrm{mg} / \mathrm{kg} \mathrm{F}$ \\
\hline $1-10$ & 1 & 1.03 \\
$11-100$ & 1 & 1.24 \\
$101-350$ & 1 & 1.12 \\
$>350$ & 1 & No data \\
\hline
\end{tabular}

Paddy farming. The difference in vulnerability between juvenile and mature paddy crops is greatest at moderate thicknesses $(16-200 \mathrm{~mm}$; Figure 7 and Table 9). This is because at $\leq 15 \mathrm{~mm}$ it is likely that all affected paddies will have impacts that do not reach or exceed IS2, and at thicknesses $>200 \mathrm{~mm}$, all affected paddies are likely to reach or exceed IS3. However, at moderate thicknesses the stage of growth of the plant will strongly dictate the vulnerability (juvenile vulnerability at $16-200 \mathrm{~mm}$ is 0.56 of the mature plant vulnerability within the same thickness range) (Figure 7 and Table 9). Rice is often grown in equatorial locations and therefore generally planted and harvested throughout the year [Chauhan et al. 2017]. Therefore, the vulnerability coefficient would need to be applied on an individual farm basis dependent on the stage of the crop and whether the paddy could be reflooded to remove tephra.

\subsubsection{Forestry}

Most forestry operations will contain trees of various ages, which complicates the formation of fragility
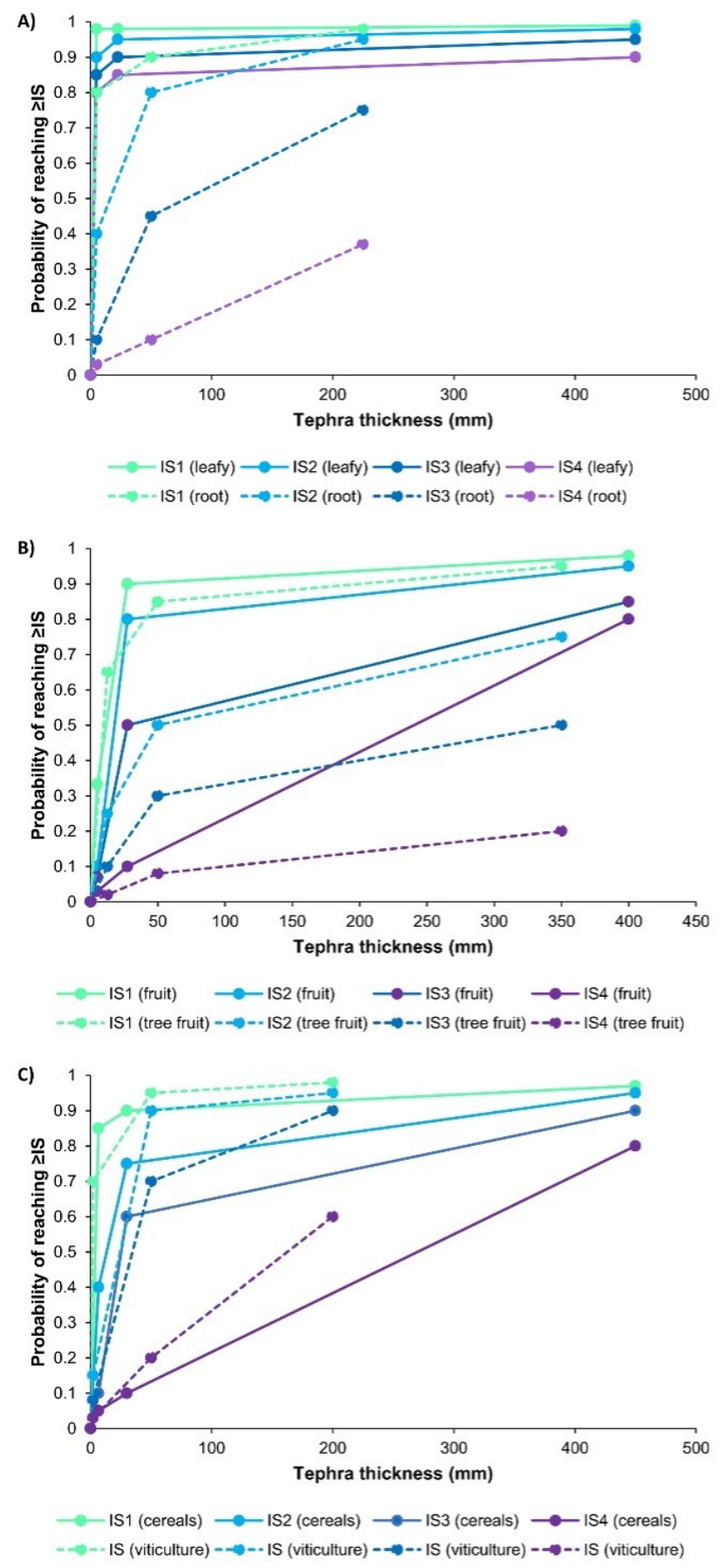

Figure 6: Horticultural crop fragility function suite for [A] root and leafy vegetables; [B] non-tree fruits and tree fruits; and [C] cereal and viticulture crops.

functions for each growth stage. Additionally, the exact age of effected trees has not usually been captured during post-impact assessments, rather the overall impacts to the forestry operation. The 19 data points used to form the fragility function for forestry are from a variety of empirical case studies and previous vulnerability studies. The higher ISs (IS3 and IS4) are poorly represented in the dataset, probably due to the very large tephra thicknesses needed to reach these states (often 


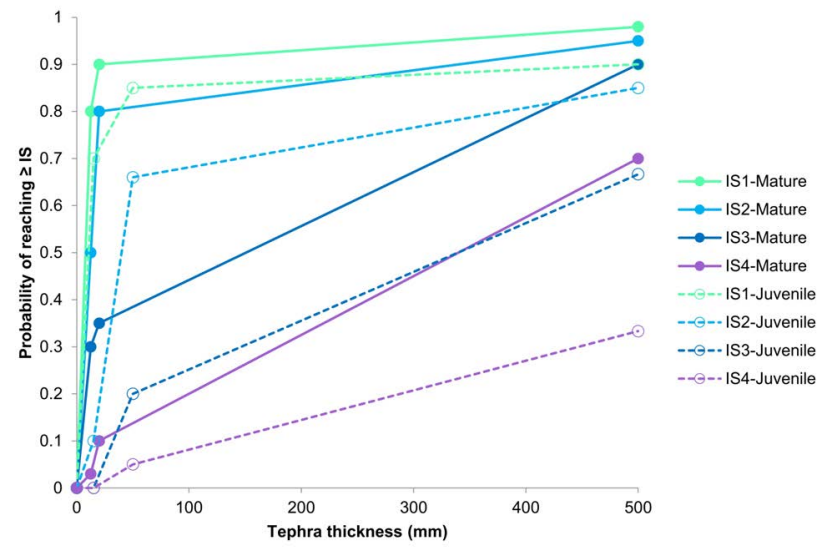

Figure 7: Fragility functions for mature and juvenile rice crops; see Table 9 for the vulnerability coefficients calculated from the set of functions.

Table 9: Vulnerability coefficients calculated from the set of functions for the fragility functions for mature and juvenile rice crops shown in Figure 7.

\begin{tabular}{lrr}
\hline Thickness $(\mathrm{mm})$ & Mature & Juvenile \\
\hline $1-15$ & 1 & 0.77 \\
$16-100$ & 1 & 0.66 \\
$101-1000$ & 1 & 0.81 \\
\hline
\end{tabular}

$>1000 \mathrm{~mm}$ ) (Table 1). Expert adjustment increased the likelihood of reaching or exceeding IS3 and IS4 to account for the dependence on road access routes for production (Figure 8).

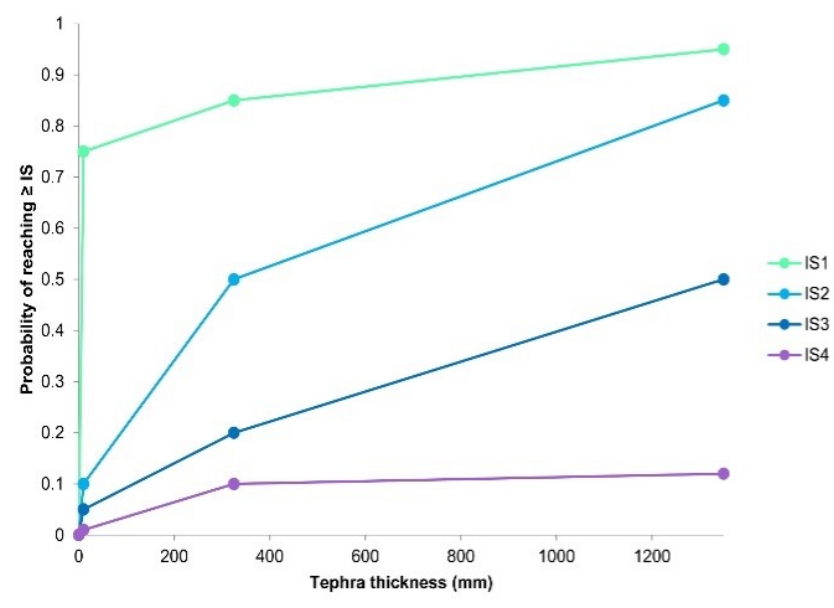

Figure 8: Forestry fragility functions.

4.3 Application of agriculture and forestry fragility functions to deterministic tephra fall scenarios

\subsubsection{Ruapehu eruptions}

The 14 October 1995 Ruapehu eruption affected large amounts of forestry and pastoral land, where sheep were the dominant livestock. One of the most widely reported agricultural impacts of the event was the death of 2,000 ewes on a large farm (2.5\% of total livestock in area) that received $\sim 5 \mathrm{~mm}$ of tephra. Deaths were attributed to suspected acute fluorosis - although animals were on very short pasture, had high energy demands, and were likely already exposed to elevated concentrations of fluoride due to application of phosphatic fertilisers on grazed pasture [Johnston 1997; Johnston et al. 2000]. Minor acid burns to tree leaves were observed in some forestry; however, this did not affect productivity [Johnston et al. 2000]. Despite fears that the eruption would affect the fruit harvest there was no reported impact after the eruption [Johnston 1997]. A small number of cauliflower crops were affected with farmers reporting losses of $\sim \mathrm{NZ} \$ 250,000$ (1995 NZ dollars) [Johnston et al. 2000]. However, most pastoral farms reported that tephra falls caused nuisance level impacts to their operations [Wilson et al. 2010], consistent with IS1 (Figure 9A), with some even reporting the benefit of the tephra deposition reducing sulphur fertilizer demands for 12-24 months [Johnston 1997; Johnston et al. 2000].

A deterministic impact assessment was undertaken using the developed fragility functions at a time of full vulnerability (as it would have been at the time of the 14 October 1995 eruption). The model forecasts relatively minor impacts, with damage to pastoral farms being confined to IS1 (Figure 10A; Supplementary Material 3A), with direct agricultural product losses estimated by the model to be $\sim \mathrm{NZ} \$ 1.2$ million (Figure 10A). Dairy and pastoral farms comprised all primary production losses predicted, whereas exposed forestry was estimated to likely recover within a production cycle (Supplementary Material 4A). Unfortunately, comprehensive reporting of direct farm losses was not made after the 1995 or 1996 Ruapehu eruptions so no comparison can be made. That said, the modelled losses are broadly consistent with reports from the time in terms of the geographic distribution of impacts and the types of agriculture that sustained losses - although workloads and anxiety did increase in rural communities suggesting that indirect losses may have been higher [Johnston 1997]. We note for context that coordination costs for agricultural assistance in 1995 from the Ministry of Agriculture (now the Ministry for Primary Industries) were $\sim \mathrm{NZ} \$ 382,500$ ( NZ\$628,600 in 2020 dollars) [Johnston et al. 2000].

Importantly, the model did not forecast the severe livestock losses seen on the sheep farm with $\sim 2,000$ animal deaths, despite the addition of the 'fluoride toxicity coefficient' (Section 3.2.3); however, losses were up to $24 \%$ greater for very proximal farms than those forecast if the fluoride concentrations had been lower. This could be due to changes in farm type distributions but is more likely explained by not accounting for the pre-eruption exposure of livestock to fluoride through fertilizer use when applying the fragility functions. 
This very specific situation highlights the contextual sensitivity of forecasting tephra impacts at individual farm-specific level, which is beyond the scope of a regional risk assessment-modelling framework such as this.

The 17 June 1996 Ruapehu eruption produced tephra falls that affected the north and western part of the central North Island (Figure 9B). The 1996 tephra deposit covered more productive farmland, as much of the thickest tephra deposits from the 1995 eruption were confined to the Tongariro National Park. Numerous dairy farms were affected by tephra fall to the north of Taupō (Figure 9B). However, reported impacts to farming following the 1996 eruption were only at nuisance to very minor levels - with the tephra fall causing livestock to stop grazing, most farmers resorted to supplementary feeding for several days in an area 100 to $200 \mathrm{~km}$ northeast of the volcano [Johnston et al. 2000].

The modelled impacts for the 1996 Ruapehu tephra fall hazard model calculate a higher number of exposed farms, with many more vulnerable dairy farms exposed. However, given the time of year, the low to moderate (depending on crop type) vulnerability coefficient reduced estimated impacts for this eruption to $\sim \mathrm{NZ} \$ 1.7$ million (Figure 10B) - relatively similar to the 1995 tephra fall scenario (NZ\$1.2 million; Figure 10A). Again, no direct farm loss data was recorded at the time, but it does seem to be within an order of magnitude of qualitative observations from the time [Cronin et al. 1997; 1998; Neild et al. 1998; Johnston et al. 2000].

Importantly, we note a key driver of increasing risk has been the change in land use in the central North Island since the 1995-96 Ruapehu eruptions, predominantly from forestry to dairy farming, which is more vulnerable to losses caused by tephra fall [Cameron and Bell 2008]. This change in farm type in the central North Island region means that if the Ruapehu eruptions occurred now, the effects on New Zealand agricultural production would be more severe than in 1995 and 1996.

\subsubsection{Kaharoa eruption}

The 1314 CE Kaharoa tephra fall event (VEI 5), produced by an eruption of Tarawera volcano, was a low probability event, with only 18 New Zealand eruptions in the last 10,000 years having a VEI of 5 or greater [Global Volcanism Program 2013]. However, it is important to consider such an event due to the potentially severe and widespread impacts such an eruption would cause. Using contemporary farm land-use distributions and types, a Kaharoa tephra fall would mean over two percent of North Island pastoral and dairying land would likely need abandoning for several months to years (IS4), and a further $0.5 \%$ would require intensive mitigative measures (IS3) (Supplementary Material 3C). The financial costs of this would have a sizable effect on the New Zealand economy. Based on current farm values and distributions, a Kaharoa event is estimated to cause $\sim \mathrm{NZ} \$ 408$ million in farming/forestry losses at a time of full vulnerability $(\sim \$ 380$ million at a time of low vulnerability), with the greatest losses to the pastoral (sheep, beef, deer farming) and dairying sectors ( $\$ 252$ million and $\$ 137$ million respectively; Figure 10C; Supplementary Material 4C). It is also likely that these losses would be even greater as lower ISs (IS1 and IS2) are likely underrepresented by the assessment, as the available isopach maps do not constrain smaller thicknesses $(<20 \mathrm{~mm})$ well due to a lack of tephra deposit preservation. A single isopach map is used to represent the eruption that occurred over a period of approximately five years; in reality tephra would have been transported by differing wind patterns within this time, covering a much larger area, but not necessarily preserved [Nairn et al. 2004]. This means that if an event were to occur today it is likely that far more farms than modelled (Figure 9C) would require supplementary feed and aid for significant periods of time (i.e. months to years). Therefore, this impact assessment presents an estimate of the minimum impacts for planning purposes.

\section{Discussion}

The use of the fragility function suite with deterministic tephra fall scenarios demonstrates the application of this method as a predictive impact assessment tool to identify areas and agricultural types with various impact severities and to target mitigation actions to appropriate locations [Wild et al. 2019]. The same approach could be used alongside forecast models in the build-up to an eruption or after an eruption using rapid field-mapping of tephra thicknesses. This approach could also be useful as a decision-making tool in the early stages of an eruption when impacts have not fully manifested, but management decisions need to be made. The IS schemes could also be adopted during post-event impact assessments to categorise observational impact information [Wilson et al. 2011b; Magill et al. 2013; Blake et al. 2015; Craig et al. 2016b; Williams et al. 2020]. This would in turn contribute to the impact dataset and the continued refinement of fragility functions. These functions and this modelling framework could also be used to produce tephra fall impact forecast maps as part of impact-based warnings, which provide a spatial and temporal estimate of tephra load/thickness expected, and also the likely consequences for specific locations, such as when the likelihood of eruption is imminent or at the time of an eruption [Harrison et al. 2014; Casteel 2016].

Due to the limited number of observations available, only a small number of data points (relative to other infrastructures and hazard types, i.e. buildings and earthquake shaking) could be used in the creation of the fragility functions. This is due to the infrequent 

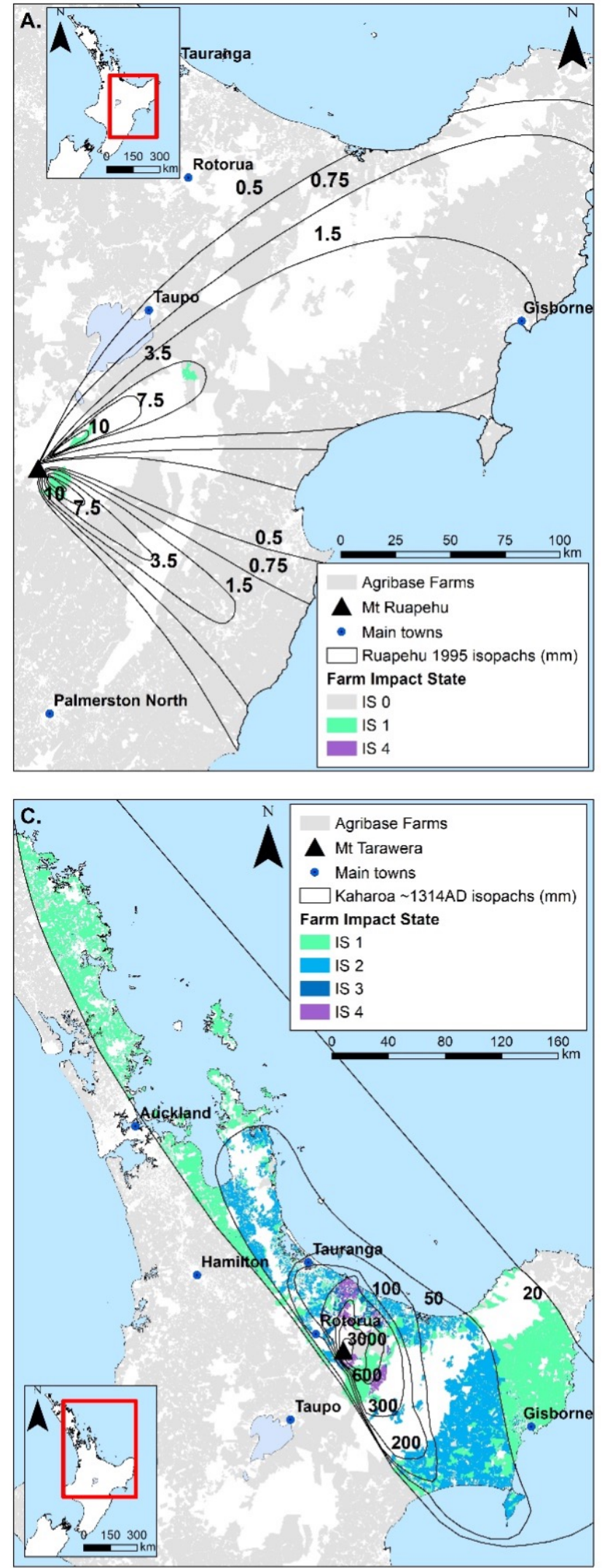

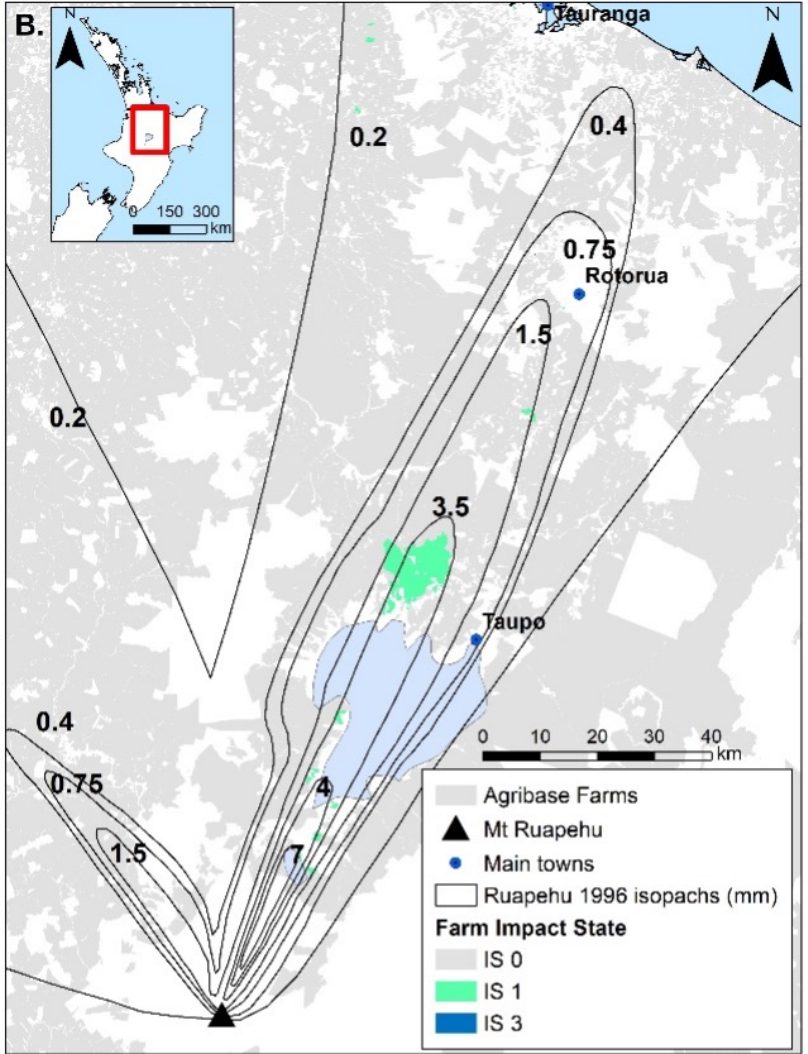

Figure 9: Impact assessment using deterministic scenarios. [A] October 1995 Ruapehu eruption; [B] June 1996 Ruapehu eruption; and [C] 1314 CE Kaharoa eruption. Isopach maps were taken from Cronin et al. [1998] for the Ruapehu events, and Sahetapy-Engel et al. [2014] for the Kaharoa tephra fall. 

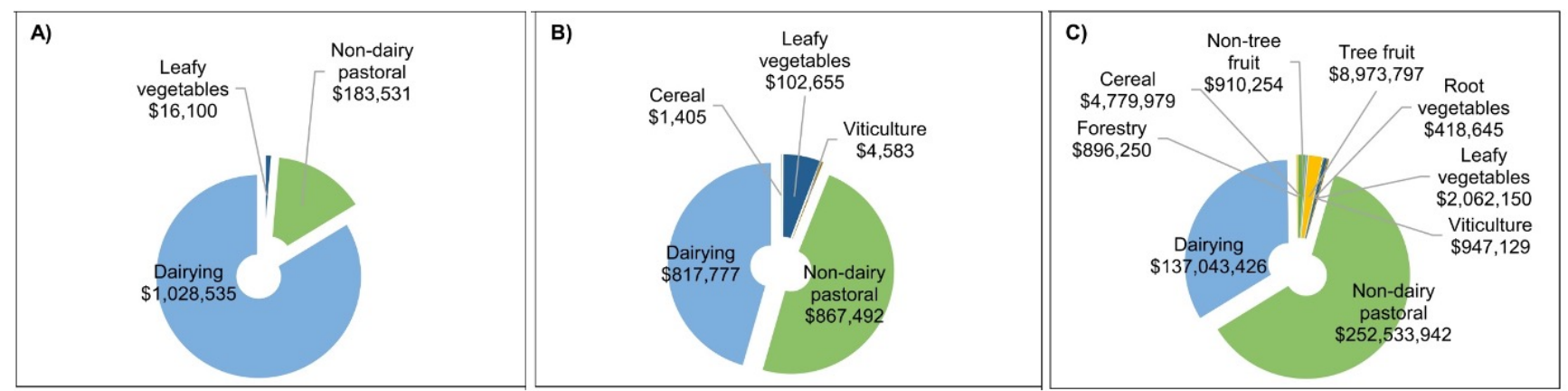

Figure 10: Financial losses (in NZ\$) for the first year due to tephra fall from an [A] October 1995 Ruapehu eruption; [B] June 1996 Ruapehu eruption; and [C] 1314 CE Kaharoa eruption. See Supplementary Material 4 for production values applied and losses per IS.

nature of large, tephra-producing volcanic eruptions, and where vulnerability data collection after these events has been inconsistent and not a priority until recently [Jenkins et al. 2014a]. This is especially evident when assessing the vulnerability of agriculture and forestry, as many previous studies have concentrated on urban impacts. Additionally, there is the assumption that the available data points form a representative sample. The inclusion of expert adjustment is required as it is highly unlikely that the data from post-event impact assessment and previous vulnerability studies alone are fully representative. This has led to a hybrid approach in the development of fragility functions [Schultz et al. 2010; Wilson et al. 2014a].

Pastoral farming is reliant on non-contaminated pasture suitable for grazing livestock. Initially after an eruption, farmers can rely on supplemental feed to maintain animal condition; however, as feed stocks dwindle or if multiple tephra fall events occur, farmers cannot return to intensive feeding for weight gain, causing potentially significant production losses [Craig et al. 2016b]. Fragility functions for high intensity pastoral farming ( $\geq 3$ animals per hectare; Figure $3 \mathrm{~A}$ ) show that they are less vulnerable to tephra fall than low intensity pastoral farms ( $<3$ units/ha; Figure $3 \mathrm{~B})$. This is likely due to greater access to feed supplies and machinery for tephra removal or cultivation [Ma et al. 2018]. High intensity farms are also less likely to occur in environmental regions prone to tephra remobilisation [Craig et al. 2016b]. For example, many low intensity farms are in semi-arid or arid regions where prolonged wind remobilisation of the tephra deposit often occurs increasing the severity of impacts [Wilson et al. 2011b]. Dairy farming is more vulnerable to tephra fall than the other types of pastoral farming (Figure 3C). This is due to the high-energy inputs required for livestock to produce milk, and the dependency on water supplies for the significant water requirements of milkproducing animals, electrical supplies for milking machinery, and road networks for transportation of milk products [Wilson and Kaye 2007]. After tephra fall, dairy farmers are often forced to reduce or discontinue milking due to a shortage of uncontaminated feed, electricity outages and/or transportation issues [Wild et al. 2019]. This can lead to cows ceasing lactation (drying off), and milking being unable to be resumed until the following milking season [McDonald et al. 2002], leading to potentially to up to one year of lost production.

Root vegetables are more resilient to tephra fall impacts relative to other horticulture, as the edible portion of the plant is underground and relatively protected [Lee et al. 2013]. However, tephra fall can still impact the vegetation above ground affecting growth, as well as creating a barrier for normal air and water exchange between the environment and the soil [Wilson et al. 2007]. In contrast, leafy vegetables, where the leafy section is the edible product, have been observed to be very vulnerable to tephra as they often have a prostrate morphology and large leaf structures that accumulate tephra and lead to smothering and limb breakage [Magill et al. 2013]. Non-tree fruit horticulture is likely to be impacted by burial by tephra fall due to its low-lying habit and the abrasion of the fruit product [Wilson and Kaye 2007], and appears to be less vulnerable to tephra fall impacts than leafy vegetables but more vulnerable than root vegetables (Figure $6 \mathrm{~A}$ and $\mathrm{B}$ ). It is assumed that this is due to the edible portion of the plant being more exposed to tephra fall than root vegetables, but less exposed than leafy vegetables, that often display a prostrate morphology [Shry and Reiley 2016]. Tree crops are also highly exposed to tephra (Figure 6B), but their structure leaves them less vulnerable to lodging or burial by tephra [Shry and Reiley 2016]. However, their vulnerability is dependent on the stage of growth. The flowering stage is most vulnerable to damage, as abrasion, chemical burns due to the acidity of tephra leachates, and injury to the flowering buds results in the abortion of fruit development [Proctor 1983]. The main damage to tree fruit crops is usually the pitting and abrasion of fruit skin due to tephra fall contamination, as well as breaking of branches and issues with harvesting machinery at larger thicknesses [Neild et al. 1998]. Cereal crops are relatively vulnerable compared to fruiting and root 
vegetables, and tree fruits (Figure 6C), as tephra accumulates between and around the florets and in the auricle structure [White and Hodgson 1999] and is difficult to remove. Additionally, cereal farming often relies on mechanical harvesting equipment which can suffer mechanical abrasion and clogging of air intakes due to the tephra deposit [Wilson et al. 2014a]. Similarly, viticulture is highly vulnerable (Figure 6C) to tephra fall due to the delicate processes of bud break, flowering, fruit set and veraison (ripening), making tephra fall removal and cleaning difficult [Keller 2015]. This means that the level of vulnerability can vary significantly with the time of year that the tephra fall occurs in. Irrigation of crops is often not sufficient to remove all tephra and hand washing may prove to be uneconomic for large scale vineyards operations [Pevreal 1993].

Forestry impacts are highly dependent on the ages of trees that each forestry operation is comprised of. Whilst mature trees are relatively resilient to tephra fall, seedlings, and trees $<10$ years old are vulnerable to branch breakages and structural damage, and new plantings are vulnerable to complete structural failure or burial [Wilson and Kaye 2007]. Another source of vulnerability for the forestry industry is the negative impact that tephra fall has on harvesting machinery and accessibility for logging trucks. In contrast to other agricultural sectors where vegetation damage is often the main cause of production loss, transportation and machinery issues cause most of the production loss for established forestry blocks [Neild et al. 1998].

Despite the lack of data on actual production loss costs from the Kaharoa and Ruapehu eruptions available for comparison, the application of the fragility function suite to the Ruapehu deterministic scenarios demonstrates the utility of the functions by identifying impacts to the same agricultural sectors (Figure 9) and in a similar geographic distribution (with the exception of areas where land-use changes from forestry to dairying have occurred post-1996). While livestock losses for Ruapehu were observed and data integrated in the development of the fragility functions, there was a lack of recorded production loss economic values limiting our ability to validate our fragility functions fully [Cronin et al. 1998; Johnston et al. 2000]. However, when such a dataset of financial loss, hazard scenario and appropriate exposure inventory becomes available, the performance of the presented fragility functions can be reviewed.

Although the collected data and the establishment of rules for expert judgement guide the adjustment of functions, any deviation from the raw dataset can increase the amount of uncertainty. Another limitation is the use of only one measure of hazard intensity (tephra thickness). Whilst there is rationale for this, impacts will also be influenced by other hazard intensity measures such as the grain size and density of the deposit, precipitation, and the duration of the tephra fall [Wilson et al. 2014a]. However, with the data currently available, it is not possible to robustly account for these factors in the proposed functions. This is noted in the development of tephra fall fragility functions for infrastructure and the built environment, where tephra thickness or load $\left(\mathrm{kg} \mathrm{m}^{-3}\right)$ are the selected HIMs [Wardman et al. 2010; Jenkins et al. 2014b; Blake et al. 2017].

The presented suite of IS schemes and fragility functions are designed to be applicable to a variety of agricultural and volcanic settings. While this study made use of an international dataset, most case-studies come from temperate environments and so the developed functions are more suited to agricultural and forestry systems found in these environments. In the absence of a more regionally specific dataset (for arid and tropical environments), these fragility functions can still be applied as part of a risk assessment; however, they will have more associated uncertainty that needs to be considered.

The fragility functions assess the production changes that a farm would experience after a tephra fall. They do not explicitly include how indirect impacts to specific interdependent systems, such as electricity or roading, would affect agricultural and forestry systems. As post-event impact assessments include more information on infrastructure impacts and the potential flow on effects for agricultural and forestry systems, fragility functions can be refined to show the differing impacts with changes to the interdependent infrastructure (e.g. the impacts to a dairy farm when road closures impede milk tanker access, compared to those which remain accessible). Currently this type of in-depth analysis is possible at a regional scale, but only for specific areas where a large amount of impact and vulnerability data is available [Wild et al. 2019]. However, using the available information, any further categorising of data was not possible whilst maintaining the ability to apply the functions for multiple regional or national scale assessments.

The functions do not consider pre-or syn-event mitigative strategies or post-event recovery measures. This is a limitation of both the development of fragility functions, but also a known constraint of temporal hazard layers across the eruption sequence, and as a result the subsequent risk assessments [e.g. Blake et al. 2017; Wilson et al. 2017; Juniper 2018; Wild et al. 2019]. These temporal factors may dramatically decrease the maximum damage/production loss received by farmers after an event, as some of the initial impact could be mitigated (e.g. by cleaning equipment) [Wild et al. 2019]. As a quantitative impact dataset is further established, a mitigation coefficient could also be developed to consider intervention and mitigation actions that might reduce the most severe impacts. These measures include actions such as cultivation, irrigation and reseeding [Sivarajan et al. 2020].

There are numerous other tephra and environmental attributes that need to be considered as modifiers to the presented fragility functions (e.g. the positive 
fertilising influence of sulphur, the $\mathrm{pH}$ of the tephra, the amount of rainfall immediately after the tephra deposition) [Cronin et al. 2000; Stewart et al. 2016]. The inclusion of such elements into assessing fragility could be informed following a similar method presented in this paper to calculate the temporality/seasonal and fluoride toxicity coefficients for pastoral farming.

\section{Conclusions}

This study presents a new set of IS schemes (for three sectors) and fragility functions (for 13 sub-sectors) for tephra impacts on agriculture and production forestry. These were primarily derived from previous vulnerability studies and an extensive review of post-event impact assessments over the last 40 years, then modified using a set of rules [Wilson et al. 2017] to account for the likelihood that the dataset is not truly representative.

The proposed fragility functions were then used to model current-day impacts to agriculture and forestry from a 1314 CE Kaharoa, 1995 Ruapehu and $1996 \mathrm{Ru}-$ apehu tephra fall. This demonstrates the potential utility of these functions in a number of ways including: 1) pre-event to create impact-based warnings, when used with tephra fall forecast maps; 2) syn-event, to assist in decision-making before agricultural and forestry impacts have fully manifested or been mapped and observed; and 3) post-event to categorise impacts to semiquantitative scale using the IS schemes developed here. The utility of the model is increased with the addition of the temporality/seasonality and fluoride toxicity coefficients, which allow for vulnerability to be increased or decreased according to when during the production cycle the tephra fall occurs and whether potentially toxic levels of fluoride are present.

Further refinement of these functions is required as more qualitative impact data become available. This should include quantification of the effect of further HIMs, environmental factors and mitigative actions within the fragility function suite, in order to provide more accurate impact models.

\section{ACKNOWLedgements}

The authors are grateful for useful discussions with Grant Wilson during function development, and to Benjamin Popovich for assistance with the RiskScape pipeline development. The authors would also like to acknowledge funding support from the Resilience to Nature's Challenge programme; National Institute of Water and Atmospheric research (NIWA) through the New Zealand Government's Science Strategic Investment Fund (SSIF) grant number CARH2106, University of Canterbury Doctoral Scholarship and University of Canterbury Mason Trust. Thank you for the thorough and insightful comments from the two anonymous reviewers and Russell Blong.

\section{Author contributions}

Vulnerability functions were developed by H. M. Craig and T. M. Wilson, with discussion and input from C. Stewart and C. Magill. A. Wild contributed to the methodological development for the deterministic impact assessments. H. M. Craig wrote the initial draft of the manuscript, processed the data, and created all figures and tables. All authors assisted in discussions and the development of the manuscript.

\section{Data aVailability}

Vulnerability functions and tephra fall deposit maps are available from the corresponding author upon request. The AgriBase ${ }^{\circledR}$ dataset was licenced from AssureQuality and is only available under a data use agreement.

Supplementary Material is available alongside the online version of this article. Supplementary Material 1: Descriptions, limitations, and examples of different vulnerability assessment methods, ranging from the simplest to the most complex; Supplementary Material 2: Asset inventory source information for risk assessment; Supplementary Material 3: Land cover (ha) and percentage of individual agricultural sector (in the North Island) exposed within each IS at full vulnerability for [A] 1995 Ruapehu; [B] 1996 Ruapehu; and [C] 1314 CE Kaharoa scenarios; Supplementary Material 4: Tables estimating the potential financial losses (in NZ\$ [MAF 2011; HorticultureNZ 2019; DairyNZ 2020]) in the first year for an [A] October $1995 \mathrm{Ru}$ apehu eruption at the October vulnerability level; [B] June 1996 Ruapehu eruption at the June vulnerability level; and [C] 1314 CE Kaharoa eruption at a time of full vulnerability.

\section{COPYRIGHT NOTICE}

(c) The Author(s) 2021. This article is distributed under the terms of the Creative Commons Attribution 4.0 International License, which permits unrestricted use, distribution, and reproduction in any medium, provided you give appropriate credit to the original author(s) and the source, provide a link to the Creative Commons license, and indicate if changes were made.

\section{REFERENCES}

Araya, O., F. Wittwer, A. Villa, and C. Ducom (1990). "Bovine fluorosis following volcanic activity in the Southern Andes." Veterinary Record 126(26), pp. 641-642.

Armienta, M. A., S. Cruz-Reyna, O. Cruz, N. Ceniceros, A. Aguayo, and M. Marin (2011). "Fluoride in ash leachates: environmental implications at 
Popocatépetl volcano, central Mexico". Natural Hazards and Earth System Sciences 11(7), pp. 1949-1956. DoI: $10.5194 /$ nhess-11-1949-2011.

Arteca, R. N. (2015). Introduction to horticultural science. Cengage Learning.

Aspinall, W. (2006). "Structured elicitation of expert judgment for probabilistic hazard and risk assessment in volcanic eruptions". Statistics in volcanology 1, pp. 15-30. Dor: 10.1144/iavcei@01.2.

AssureQuality (2015). AgriBase ${ }^{\circledR}$ agricultural dataset. AssureQuality, Wellington. Univeristy of Canterbury Subcontract 2013.

Ayris, P. M. and P. Delmelle (2012). "The immediate environmental effects of tephra emission". Bulletin of volcanology 74(9), pp. 1905-1936. DOI: 10.1007 / s00445-012-0654-5.

Barnard, S. T. (2003). "Potential physical effects of any future 1886 type eruption from Tarawera Volcano on the Bay of Plenty Region". MA thesis. University of Canterbury.

Biass, S., A. Todde, R. Cioni, M. Pistolesi, N. Geshi, and C. Bonadonna (2017). "Potential impacts of tephra fallout from a large-scale explosive eruption at Sakurajima volcano, Japan”. Bulletin of Volcanology 79(10), pp. 1-24. DoI: 10.1007/s00445-017-1153-5.

Blake, D., G. Wilson, C. Stewart, H. Craig, J. Hayes, S. Jenkins, T. Wilson, C. Horwell, R. Daniswara, and D. Ferdiwijaya (2015). Impacts of the 2014 eruption of Kelud volcano, Indonesia on infrastructure, utilities, agriculture, and health. GNS Science Report 2015/15. GNS Science.

Blake, D. M., N. I. Deligne, T. M. Wilson, and G. Wilson (2017). "Improving volcanic ash fragility functions through laboratory studies: example of surface transportation networks". Journal of Applied Volcanology 6(1), pp. 1-18. DoI: 10.1186/s13617-017-0066-5.

Blake, D. M., T. M. Wilson, and C. Gomez (2016). "Road marking coverage by volcanic ash: an experimental approach". Environmental Earth Sciences 75(20), pp. 1-12. Dor: 1348.10.1007/s12665-016-6154-8.

Blake, D. M., T. M. Wilson, and C. Stewart (2018). "Visibility in airborne volcanic ash: considerations for surface transportation using a laboratory-based method". Natural Hazards 92(1), pp. 381-413. Dor: 381-413.10.1007/s11069-018-3205-3.

Blong, R. J. (2003). "A review of damage intensity scales". Natural hazards 29(1), pp. 57-76. DoI: 10 . 1023/A : 1022960414329.

- (2012). Volcanic hazards: a sourcebook on the effects of eruptions. Elsevier.

Cabré, J., M. Aulinas, M. Rejas, and J. L. FernandezTuriel (2016). "Volcanic ash leaching as a means of tracing the environmental impact of the 2011 Grímsvötn eruption, Iceland". Environmental Science and Pollution Research 23(14), pp. 14338-14353. DoI: 10.1007/s11356-016-6559-7.

Cameron, M. P. and K. Bell (2008). Dairying in the Waikato region of New Zealand: An overview of histor- ical statistics. No. 13/08. Department of Economics Working Paper Series.

Casteel, M. A. (2016). "Communicating increased risk: An empirical investigation of the National Weather Service's impact-based warnings". Weather, Climate, and Society 8(3), pp. 219-232. Dor: 10.1175/wcas-d15-0044. 1.

Chauhan, B. S., K. Jabran, and G. Mahajan (2017). Rice production worldwide. Vol. 247. Springer.

Cook, R. J., J. C. Barron, R. I. Papendick, and G. J. Williams (1981). "Impact on agriculture of the Mount St. Helens eruptions". Science 211(4477), pp. 16-22. Dor: 16-22.10.1126/science.211.4477. 16.

Craig, H., T. M. Wilson, C. Stewart, V. Outes, G. Villarosa, and P. Baxter (2016a). "Impacts to agriculture and critical infrastructure in Argentina after ashfall from the 2011 eruption of the Cordón Caulle volcanic complex: an assessment of published damage and function thresholds". Journal of Applied Volcanology 5(1), pp. 1-31. Dor: 10.1186/s13617-016-๑๑46-1. Craig, H., T. M. Wilson, C. Stewart, G. Villarosa, V. Outes, S. Cronin, and S. Jenkins (2016b). "Agricultural impact assessment and management after three widespread tephra falls in Patagonia, South America". Natural Hazards 82(2), pp. 1167-1229. DoI: 1167-1229.10.1007/s11069-016-2240-1.

Cronin, S. J., M. J. Hedley, V. E. Neall, and R. G. Smith (1998). "Agronomic impact of tephra fallout from the 1995 and 1996 Ruapehu Volcano eruptions, New Zealand". Environmental Geology 34(1), pp. 21-30. DoI: $10.1007 / \mathrm{s} 002540050253$.

Cronin, S. J., M. J. Hedley, R. G. Smith, and V. E. Neall (1997). "Impact of Ruapehu ash fall on soil and pasture nutrient status 1. October 1995 eruptions". New Zealand Journal of Agricultural Research 40(3), pp. 383-395. DoI: 10.1080/00288233.1997.9513260.

Cronin, S. J., V. Manoharan, M. J. Hedley, and P. Loganathan (2000). "Fluoride: A review of its fate, bioavailability, and risks of fluorosis in grazedpasture systems in New Zealand". New Zealand Journal of Agricultural Research 43(3), pp. 295-321. Dor: 10.1080/00288233.2000.9513430.

Cronin, S. J., V. E. Neall, J. A. Lecointre, M. J. Hedley, and P. Loganathan (2003). "Environmental hazards of fluoride in volcanic ash: a case study from Ruapehu volcano, New Zealand". Journal of Volcanology and Geothermal Research 121(3-4), pp. 271-291. DoI: $10.1016 / \mathrm{S} 0377-0273(02) 00465-1$.

Cronin, S. J., C. Stewart, A. V. Zernack, M. Brenna, J. N. Procter, N. Pardo, B. Christenson, T. Wilson, R. B. Stewart, and M. Irwin (2014). "Volcanic ash leachate compositions and assessment of health and agricultural hazards from 2012 hydrothermal eruptions, Tongariro, New Zealand". Journal of volcanology and geothermal research 286, pp. 233-247. DoI: $10.1016 / \mathrm{j}$. jvolgeores . 2014.07.002. 
Dahlgren, R. A., F. C. Ugolini, and W. H. Casey (1999). "Field weathering rates of Mt. St. Helens tephra". Geochimica et Cosmochimica Acta 63(5), pp. 587-598. DOI: $10.1016 /$ S0016-7037 (99) $00067-8$.

DairyNZ (2018). Farm management calendar. https:// WwW . dairynz . co . nz/publications/seasonal / farmmanagement-calendar/. Accessed: 2020-03-30.

- (2020). DairyNZ economic survey, Hamilton, NZ. https: / /www . dairynz . co .nz/publications/dairyindustry/dairynz-economic-survey-2018-19/. Accessed: 2020-08-15.

Eggler, W. A. (1963). "Life of Paricutín volcano, México, eight years after ceased activity". American Midland Naturalist 69(1), pp. 38-68. Dor: 10.2307/2422843.

Flueck, W. T. (2013). "Effects of fluoride intoxication on teeth of livestock due to recent volcanic eruptions in Patagonia, Argentina". Online Journal of Veterinary Research 17(4), pp. 167-176.

- (2016). "The impact of recent volcanic ash depositions on herbivores in Patagonia: a review". The Rangeland Journal 38(1), pp. 27-34. Dor: 10.1071 / Rj14124.

Georgsson, G. and G. Petursson (1972). "Fluorosis of sheep caused by the Hekla eruption in 1970". Fluoride 5 .

Global Volcanism Program (2013). Volcanoes of the World, v. 4.9.1 (17 Sep 2020). Ed. by E. Venzke. Accessed: 2020-11-01. DoI: ๑.5479/si.GVP. VOTW4-2013.

Harrison, J., C. McCoy, K. Bunting-Howarth, H. Sorensen, K. Williams, and C. Ellis (2014). Evaluation of the National Weather Service impact-based warning tool. NWS Central Region Headquarters.

Hayes, J. L., N. . Deligne, L. Bertin, R. Calderon, J. . Wardman, T. M. Wilson, G. S. Leonard, C. Stewart, K. L. Wallace, and P. J. Baxter (2019). Impacts of the 2015 eruption of Calbuco volcano on Chilean infrastructure, utilities, agriculture, and health. GNS Science report 2019/04. GNS Science. DOI: $10.21420 / 02 \mathrm{YC}-$ vX66.

HorticultureNZ (2019). Fresh Facts, Wellington. https: //www . freshfacts . co . nz/files/freshfacts-2019. pdf. Accessed: 2020-03-03.

Inbar, M., H. A. Ostera, C. A. Parica, M. B. Remesal, and F. M. Salani (1995). "Environmental assessment of 1991 Hudson volcano eruption ashfall effects on southern Patagonia region, Argentina". Environmental Geology 25(2), pp. 119-125. DoI: 10.1007 / Bf00767868.

Jenkins, S. F., R. J. S. Spence, J. F. B. D. Fonseca, R. U. Solidum, and T. M. Wilson (2014a). "Volcanic risk assessment: Quantifying physical vulnerability in the built environment". Journal of Volcanology and Geothermal Research 276, pp. 105-120. DoI: 10.1016/ j. jvolgeores.2014.03.002.

Jenkins, S., T. M. Wilson, C. Magill, V. Miller, C. Stewart, W. Marzocchi, and M. Boulton (2014b). Volcanic ash fall hazard and risk. Technical background paper for the UN-ISDR 2015 global assessment report on disaster risk reduction.
Johnston, D. M. (1997). "Physical and social impacts of past and future volcanic eruptions in New Zealand". PhD Thesis. Massey University, Palmerston North, New Zealand.

Johnston, D. M., B. F. Houghton, V. E. Neall, K. R. Ronan, and D. Paton (2000). "Impacts of the 1945 and 1995-1996 Ruapehu eruptions, New Zealand: an example of increasing societal vulnerability". Geological Society of America Bulletin 112(5), pp. 720-726. DOI: $10.1130 / 0016-7606(2000) 112 \backslash \% 3 C 720$ : iotare $\backslash$ \%3E2. $0 . \mathrm{co} ; 2$.

Juniper, Z. (2018). "Risk assessment of the petroleum exploration and production industry from volcanic hazards in the Taranaki region, New Zealand". MA thesis. University of Canterbury, Christchurch, New Zealand.

Keller, M. (2015). The science of grapevines: anatomy and physiology. Academic Press. DoI: 10.1016/C2013-006797-7.

Lee, Y.-J., S.-D. Kim, J. Chun, and G. Woo (2013). "Estimation of economic losses on the agricultural sector in Gangwon province, Korea, based on the Baekdusan Volcanic Ash Damage Scenario". Journal of the Korean Earth Science Society 34(6), pp. 515-523. DoI: 10.5467/jkess.2013.34.6.515.

Ma, W., A. Renwick, and K. Bicknell (2018). "Higher intensity, higher profit? Empirical evidence from dairy farming in New Zealand". Journal of Agricultural Economics 69(3), pp. 739-755. DoI: 10.1111/1477-9552. 12261.

MAF (2011). Farm monitoring overview, Ministry of Agriculture and Forestry, Wellington. https : / / www . mpi . govt . nz / resources - and - forms / economic intelligence / farm-monitoring/. Accessed: 202009-10.

Magill, C., T. Wilson, and T. Okada (2013). "Observations of tephra fall impacts from the 2011 Shinmoedake eruption, Japan". Earth, Planets and Space 65(6), pp. 677-698. Dor: 10.5047/eps. 2013.05.010.

Manaaki Whenua Landcare Research (2020). Land Cover Database version 5.0, Manaaki Whenua - Landcare Research, LRIS Portal. https://Iris. scinfo. org . nz / layer / 104400 - lcdb - v50 - land - cover database-version-50-mainland-new-zealand/. Accessed: 2020-05-12.

McDonald, P., C. A. Greenhalgh J. F. D. ad Morgan, R. Edwards, L. Sinclair, and R. Wilkinson (2002). Animal nutrition. $6^{\text {th }}$. Pearson education.

Mercado, R. A. (1996). "Socioeconomic impacts of the Mount Pinatubo eruption". Fire and Mud: eruptions and lahars of Mount Pinatubo, Philippines, pp. 10631069.

MIAVITA (2012). Handbook for volcanic risk management-prevention, crisis management, resilience. Ed. by C. Bignami, V. Bosi, L. Costantini, C. Cristiani, F. Lavigne, and P. Thierry. BRMG Orleans. Dor: 10.13140/ 2.1.2167.0083. 
Nairn, I. A., P. R. Shane, J. W. Cole, G. J. Leonard, S. Self, and N. Pearson (2004). "Rhyolite magma processes of the AD 1315 Kaharoa eruption episode, Tarawera volcano, New Zealand". Journal of Volcanology and Geothermal Research 131(3-4), pp. 265-294. Dor: 10. 1016/S0377-0273(03)00381- 0 .

Neild, J., P. O’Flaherty, P. Hedley, R. Underwood, D. Johnston, B. Christenson, and P. Brown (1998). Impact of a volcanic eruption on agriculture and forestry in New Zealand. 99. MAF policy technical paper, p. 101.

Pevreal, C. W. (1993). "Volcanic impact to viticulture in the Hawke's Bay". BSc Thesis. University of Canterbury, Christchurch, New Zealand.

Porter, K., R. Kennedy, and R. Bachman (2007). "Creating fragility functions for performance-based earthquake engineering". Earthquake Spectra 23(2), pp. 471-489. DOI: 10.1193/1.2720892.

Proctor, J. T. A. (1983). "Effect of simulated sulfuric acid rain on apple tree foliage, nutrient content, yield and fruit quality". Environmental and Experimental Botany 23(2), pp. 167-174. DOI: $10 \cdot 1016 / 0098-$ 8472(83) 90036-9.

Rees, J. (1979). "Effects of the Eruption of Parícutin Volcano on Landforms, Vegetation, and Human Occupancy". Volcanic Activity and Human Ecology. Ed. by P. D. Sheets and D. K. Grayson. Academic Press, pp. 249-292. DOI: $10.1016 /$ B978-0-12-639120$6.50014-5$.

Reese, S., A. King, R. Bell, J. Schmidt, L. Oxley, and D. Kulasiri (2007). "Regional RiskScape: a multihazard loss modelling tool". MODSIM 2007 International Congress on Modelling and Simulation. Citeseer, pp. 1681-1687.

Reese, S. and D. Ramsay (2010). Riskscape: flood fragility methodologies. Technical Report: WLG201045. NIWA.

Reese, S., B. A. Bradley, J. Bind, G. Smart, W. Power, and J. Sturman (2011). "Empirical building fragilities from observed damage in the 2009 South Pacific tsunami". Earth-Science Reviews 107(1-2), pp. 156173. DoI: $10.1016 / \mathrm{j}$. earscirev.2011.01.009.

Reyes, R. Y. and H. U. Neue (1991). "Characterization of the volcanic ejecta from Mount Pinatubo and its impact on rice production". Philippine Journal Crop Science 16(2), pp. 69-73.

Rossetto, T., I. Ioannou, and D. Grant (2013). Existing empirical fragility and vulnerability relationships: compendium and guide for selection. GEM Technical Report. GEM Foundation, Pavia.

Rossetto, T., I. Ioannou, D. Grant, and T. Maqsood (2014). Guidelines for the empirical vulnerability assessment. GEM Technical Report. GEM Foundation, Pavia.

Rossetto, T. and I. Ioannou (2018). "Empirical fragility and vulnerability assessment: not just a regression". Risk Modeling for Hazards and Disasters. Elsevier, pp. 79-103. DOI: $10.1016 /$ b978-0-12-804071-3 . $00004-5$.

Rubin, C. H., E. K. Noji, P. J. Seligman, J. L. Holtz, J. Grande, and F. Vittani (1994). "Evaluating a fluorosis hazard after a volcanic eruption". Archives of Environmental Health: An International Journal 49(5), pp. 395-401. DoI: 10.1080/00039896.1994.9954992.

Sahetapy-Engel, S., S. Self, R. J. Carey, and I. A. Nairn (2014). "Deposition and generation of multiple widespread fall units from the c. AD 1314 Kaharoa rhyolitic eruption, Tarawera, New Zealand". Bulletin of Volcanology 76(8), pp. 1-28. DOI: 10.1007/s00445014-0836-4.

Schultz, M. T., B. P. Gouldby, J. Simm, and J. T. Wibowo (2010). Beyond the factor of safety developing fragility curves to characterize system reliability. GEM Technical Report ERDC SR-10-1. US Army Corps of Engineers.

Shry, C. and H. E. Reiley (2016). Introductory horticulture. Cengage Learning.

Sivarajan, S. P., J. Lindsay, S. J. Cronin, and T. M. Wilson (2017). "Remediation and recovery techniques for volcanic ash-affected pasture soils of New Zealand". Science and policy: nutrient management challenges for the next generation. Ed. by L. D. Currie and M. J. Hedley. Fertilizer and Lime Research Centre, Massey University, Palmerston North, New Zealand.

Sivarajan, S., J. Lindsay, S. Cronin, and T. Wilson (2020). 'Farmers' perceptions of options for pasture remediation and recovery following major tephra fall in New Zealand". Australasian Journal of Disaster and Trauma Studies 24(2), pp. 89-102.

Stewart, C., H. M. Craig, S. Gaw, T. Wilson, G. Villarosa, V. Outes, S. Cronin, and C. Oze (2016). "Fate and agricultural consequences of leachable elements added to the environment from the 2011 Cordón Caulle tephra fall". Journal of Volcanology and Geothermal Research 327, pp. 554-570. Dor: 10.1016/ j. jvolgeores. 2016.09.017.

Stewart, C., D. E. Damby, I. Tomašek, C. J. Horwell, G. S. Plumlee, M. A. Armienta, M. G. R. Hinojosa, M. Appleby, P. Delmelle, S. Cronin, et al. (2020). "Assessment of leachable elements in volcanic ashfall: a review and evaluation of a standardized protocol for ash hazard characterization". Journal of Volcanology and Geothermal Research 392, p. 106756. Dor: 10. 1016/j . jvolgeores. 2019.106756.

Sword-Daniels, V., J. Wardman, C. Stewart, T. Wilson, D. Johnston, and T. Rossetto (2011). Infrastructure impacts, management and adaptations to eruptions at Volcán Tungurahua, Ecuador, 1999-2010. GNS Science Report 2011/24. GNS Science.

Tarbotton, C., F. Dall'Osso, D. Dominey-Howes, and J. Goff (2015). "The use of empirical vulnerability functions to assess the response of buildings to tsunami impact: comparative review and summary of best practice". Earth-Science Reviews 142, pp. 120-134. DoI: $10.1016 / \mathrm{j}$. earscirev.2015.01.002. 
Thompson, M. A., J. M. Lindsay, T. M. Wilson, S. Biass, and L. Sandri (2017). "Quantifying risk to agriculture from volcanic ashfall: a case study from the Bay of Plenty, New Zealand". Natural Hazards 86(1), pp. 31-56. DOI: 10.1007/s11069-016-2672-7.

Thorarinsson, S. and G. E. Sigvaldason (1972). "The Hekla eruption of 1970". Bulletin Volcanologique 36(2), pp. 269-288. Dor: 10.1007/bf02596870.

Wantim, M. N., C. Bonadonna, C. E. Gregg, S. Menoni, C. Frischknecht, M. Kervyn, and S. N. Ayonghe (2018). "Forensic assessment of the 1999 Mount Cameroon eruption, West-Central Africa". Journal of Volcanology and Geothermal Research 358, pp. 13-30. DoI: $10.1016 / \mathrm{j}$. jvolgeores. 2018.06.007.

Wardman, J., V. Sword-Daniels, C. Stewart, T. Wilson, D. Johnston, and T. Rossetto (2012). Impact assessment of the May 2010 eruption of Pacaya volcano. GNS Science Report 2012/09. GNS Science.

Wardman, J., T. M. Wilson, J. W. Cole, P. Bodger, and D. Johnston (2010). "Quantifying the vulnerability of high voltage power transmission systems to volcanic ashfall hazards". Electricity Engineers 'Association (EEA) Conference E Exhibition.

White, J. and J. Hodgson (1999). New Zealand pasture and crop science. Oxford University Press.

Wild, A. J., T. M. Wilson, M. S. Bebbington, J. W. Cole, and H. M. Craig (2019). "Probabilistic volcanic impact assessment and cost-benefit analysis on network infrastructure for secondary evacuation of farm livestock: A case study from the dairy industry, Taranaki, New Zealand". Journal of Volcanology and Geothermal Research 387, p. 106670. DoI: 10.1016/j . jvolgeores . 2019. 106670.

Williams, G. T., S. F. Jenkins, S. Biass, H. E. Wibowo, and A. Harijoko (2020). "Remotely assessing tephra fall building damage and vulnerability: Kelud Volcano, Indonesia". Journal of Applied Volcanology 9(1), pp. 1-18. Dor: 10.1186/s13617-020-00100-5.

Wilson, G., T. M. Wilson, N. I. Deligne, and J. W. Cole (2014a). "Volcanic hazard impacts to critical infrastructure: A review". Journal of Volcanology and Geothermal Research 286, pp. 148-182. DoI: 10.1016/ j. jvolgeores.2014.08.030.

Wilson, G., T. M. Wilson, N. I. Deligne, D. M. Blake, and J. W. Cole (2017). "Framework for developing volcanic fragility and vulnerability functions for critical infrastructure". Journal of Applied Volcanology 6(1), pp. 1-24. DoI: 10.1186/s13617-017-0065-6.

Wilson, T. M. and J. W. Cole (2007). "Potential impact of ash eruptions on dairy farms from a study of the ef- fects on a farm in eastern Bay of Plenty, New Zealand; implications for hazard mitigation". Natural Hazards 43(1), pp. 103-128. DoI: 10.1007/s11069-007-91118.

Wilson, T. M., J. W. Cole, S. Cronin, C. Stewart, and D. Johnston (2011a). "Impacts on agriculture following the 1991 eruption of Vulcan Hudson, Patagonia: lessons for recovery". Natural Hazards 57(2), pp. 185212. DOI: $10.1007 / \mathrm{s} 11069-010-9604-8$.

Wilson, T. M., J. W. Cole, C. Stewart, S. Cronin, and D. Johnston (2011b). "Ash storms: impacts of windremobilised volcanic ash on rural communities and agriculture following the 1991 Hudson eruption, southern Patagonia, Chile". Bulletin of Volcanology 73(3), pp. 223-239. DoI: $10.1007 /$ s $00445-010-0396-$ 1.

Wilson, T. M. and G. D. Kaye (2007). Agricultural fragility estimates for volcanic ash fall hazards. GNS Science Report 2007/37. GNS Science.

Wilson, T. M., G. Kaye, C. Stewart, and J. W. Cole (2007). Impacts of the 2006 eruption of Merapi volcano, Indonesia, on agriculture and infrastructure. GNS Science Report 2007/07. GNS Science.

Wilson, T. M., C. Stewart, J. W. Cole, D. Johnston, and S. Cronin (2010). "Vulnerability of farm water supply systems to volcanic ash fall". Environmental Earth Sciences 61(4), pp. 675-688. DoI: 10.1007 / s12665$009-0380-2$.

Wilson, T. M., C. Stewart, V. Sword-Daniels, G. S. Leonard, D. M. Johnston, J. W. Cole, J. Wardman, G. Wilson, and S. T. Barnard (2012). "Volcanic ash impacts on critical infrastructure". Physics and Chemistry of the Earth, Parts $A / B / C$ 45, pp. 5-23. DoI: 10 . 1016/j.pce. 2011.06 .006 .

Wilson, T. M., C. Stewart, J. B. Wardman, G. Wilson, D. M. Johnston, D. Hill, S. J. Hampton, M. Villemure, S. McBride, G. Leonard, et al. (2014b). "Volcanic ashfall preparedness poster series: a collaborative process for reducing the vulnerability of critical infrastructure". Journal of Applied Volcanology 3(1), pp. 125. DoI: $10.1186 / \mathrm{s} 13617-014-0010-\mathrm{x}$.

Yu, S., Y.-J. Lee, S.-M. Yoon, and K.-H. Choi (2014). "Economic loss estimation of mt. Baekdu eruption scenarios". Economic and Environmental Geology 47(3), pp. 205-217. Dor: 10.9719/eeg. 2014.47.3.205.

Zuccaro, G., F. Cacace, R. J. S. Spence, and P. J. Baxter (2008). "Impact of explosive eruption scenarios at Vesuvius". Journal of Volcanology and Geothermal Research 178(3), pp. 416-453. Dor: $10.1016 / j$. jvolgeores. 2008.01.005. 